RACHAEL LONG, University of California Cooperative Extension Farm Advisor, Yolo County;

TOM GULYA, Research Plant Pathologist, Retired, USDA-ARS, Fargo, ND;

SARAH LIGHT, University

of California Cooperative Extension Farm Advisor, Sutter-

Yuba Counties;

KHALED BALI, University

of California Cooperative

Extension Irrigation Water

Management Specialist,

Kearney Agricultural Research

and Extension Center;

\section{KONRAD MATHESIUS,}

University of California Cooperative Extension Farm Advisor, Yolo County;

\section{ROLAND D. MEYER,}

University of California

Cooperative Extension Soils

Specialist Emeritus, University of

California, Davis

\title{
Sunflower Hybrid Seed Production in California
}

unflowers (Helianthus annuus) are grown in
California for the hybrid seed, the planting

stock destined to be planted in many areas around the world for oilseed and confectionary snack food markets. Hybrid sunflower seed is primarily grown in California's Sacramento Valley, though there is a small but growing acreage in the Imperial Valley. The main counties where sunflowers are grown include Colusa, Solano, Glenn, Sutter, and Yolo, along with smaller acreages in Butte, Imperial, Sacramento, Tehama, and Yuba counties (fig. 1). California produced about 50,000 acres of certified hybrid seed in 2017, but acreage varies yearly, depending on market demands (fig. 2). The Sacramento Valley is world renowned as a premier location for sunflower seed production due to the
Mediterranean climate with hot, dry summers and excellent field isolation capabilities for seed purity. This ensures relatively disease-free seed to meet the phytosanitary restrictions required for export, as imposed by importing countries. California is the number one sunflower seed producing state in the United States.

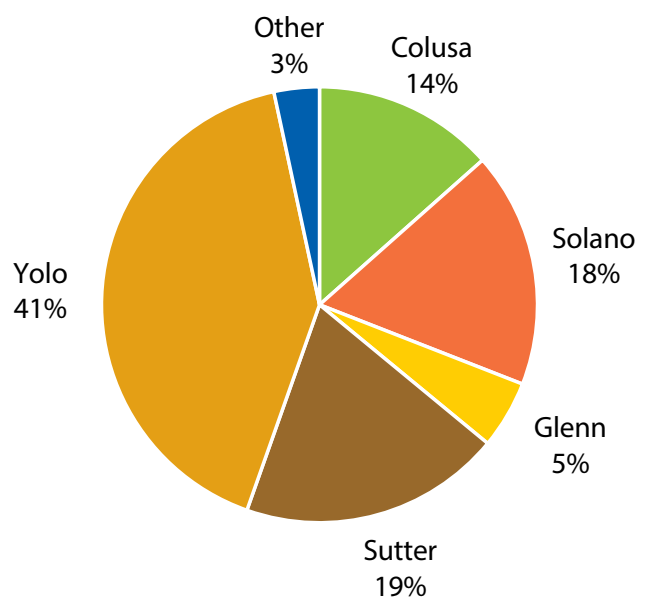

Figure 1. Percent certified hybrid sunflower seed averaged by California county, 2008-17. "Other" includes Butte, Imperial, Sacramento, Tehama, and Yuba Counties. Source: CCIA 2018a. 


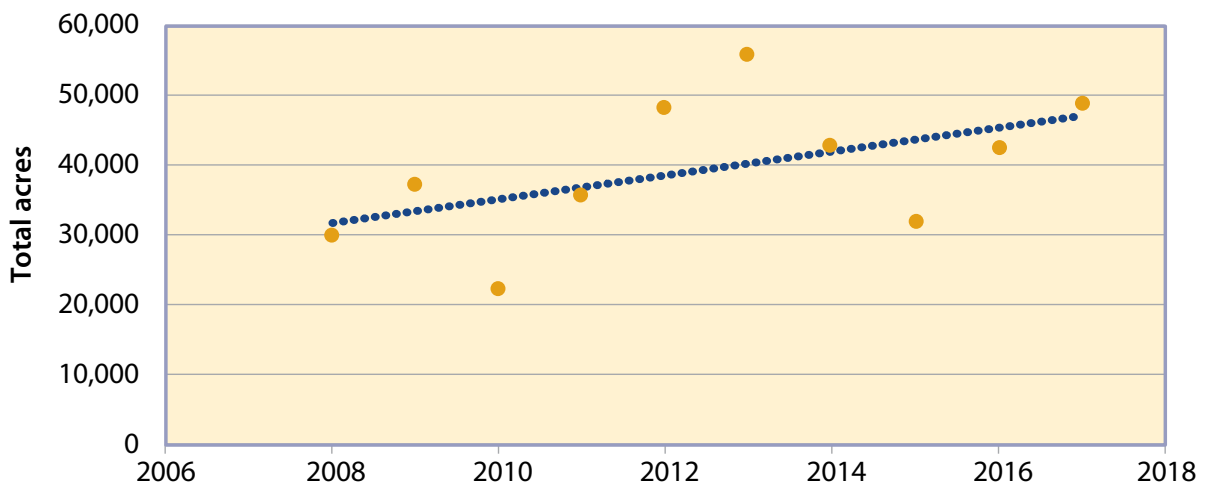

Figure 2. Total certified hybrid sunflower seed acreage in California. Source: CCIA 2018 .

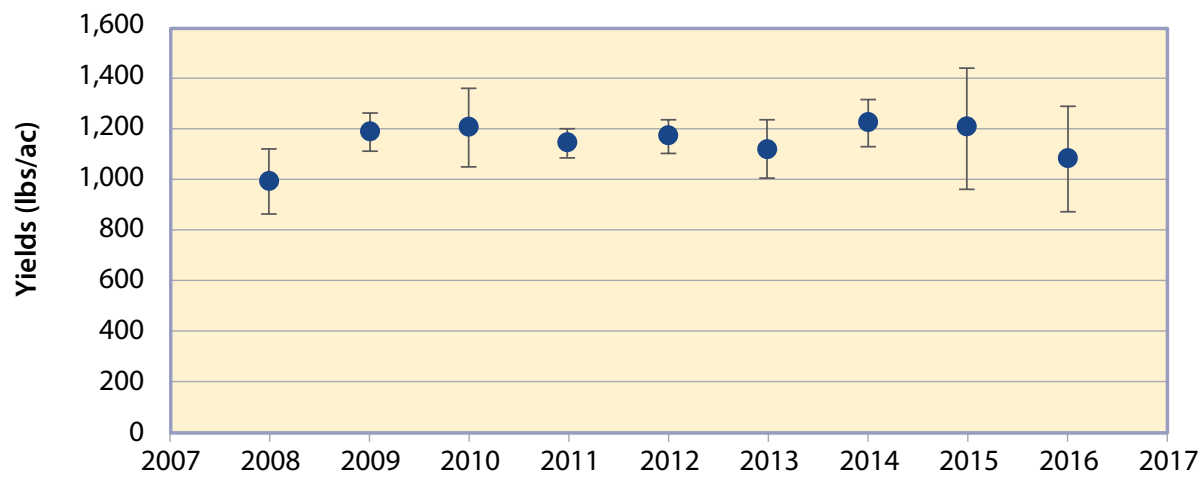

Figure 3. Sunflower certified hybrid seed gross average yields from female lines (pounds per acre, \pm SEM). Source: CDFA 2018.

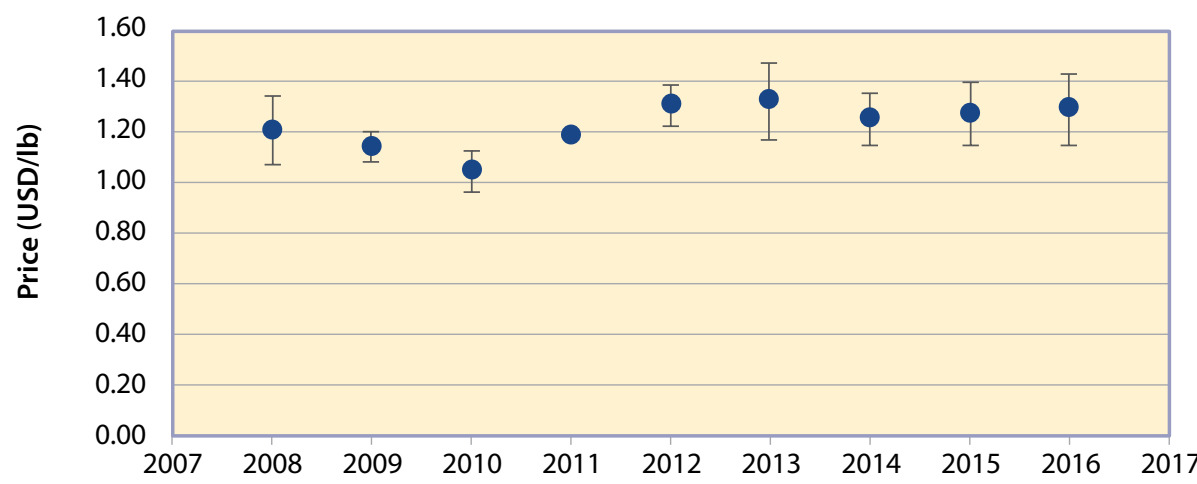

Figure 4. Sunflower certified hybrid seed value per pound (USD, \pm SEM) at harvest before cleanout. Source: CDFA 2018.
Hybrid sunflower seed production involves planting male-fertile parental lines (pollen-producing; hereafter, "males") and malesterile parental lines (no pollen; hereafter, "females") in separate rows within a field. Cross-pollination between the two lines produces a hybrid seed that contains the best traits of each parent. Males generally have multiple flowers per plant, compared with female plants with a single composite flower. Honey bees are relied on to move pollen from the male to female lines. After pollination, when the seeds are set, growers chop the male rows to prevent any male seeds from contaminating the female lines at harvest. When the female sunflower stalks dry down at the end of the growing season, they are harvested, with yields averaging 1,200 pounds per acre, depending on the yield potential of the female parent (fig. 3). Prices paid to seed growers averaged $\$ 1.30$ per pound over the past 5 -years, depending on the hybrid, with lower yielding types having higher prices (fig. 4). The value of planting seed is about five to ten times that of a commercial oil or confectionary seed crop.

Sunflower, and other members of this genus, are native to North America. They were domesticated thousands of years ago and likely favored as an important high-energy food source by Native Americans. For the oil-seed market, sunflower oil is often preferred by the food processing industry because it is stable at high cooking temperatures. The oil also supplies more vitamin $\mathrm{E}$ than any other vegetable oil, and the varieties with high levels of oleic oil deliver low levels of saturated fat. The small-seeded oil types are also important for birdseed markets. For the confectionary market, the non-oil, large-seeded white-stripe sunflower types are important for the snack food industry. Sunflowers are favored in crop rotations by farmers because they help in the long-term management of weeds and diseases and they are a profitable specialty crop, as shown in the sunflower cost of production study by Long et al. (2018), http:// coststudies.ucdavis.edu.

California produces nearly all of the domestic hybrid sunflower planting seed destined for Midwest markets. The United States grows about 1.7 million acres of sunflower, mostly for oil, primarily in the Dakotas, although the production area stretches south to the panhandle of Texas. In most years, about 25 percent of California's 
hybrid sunflower seed goes to international markets, though in some years it can be as high as 60 percent. Russia and Ukraine are California's largest export markets, where more than 50 million acres of sunflowers is grown for oil, followed by China and the European Union.

\section{CROP PRODUCTION METHODS}

\section{Stages of Growth}

Management practices for sunflower production depend on the growth stage of the plants (table 1). A full description and photographs of these different stages can be found in Stages of

Table 1. Description of sunflower growth stages

\begin{tabular}{|l|l|l|}
\hline Stage & Description \\
\hline Vegetative emergence (VE) \\
\hline VE & Seedling has emerged and the first true leaf beyond the cotyledons is $<4 \mathrm{~cm}$. \\
\hline Vegetative stages (V) \\
\hline V1, V2, etc. & $\begin{array}{l}\text { V(x) indicates the number of true leaves in the vegetative stage at least } 4 \\
\text { cm long, beginning with V1, V2, V3, etc. Count leaf scars for senesced lower } \\
\text { leaves, excluding cotyledon node. }\end{array}$ \\
\hline Reproductive stages (R) \\
\hline R1 & $\begin{array}{l}\text { The terminal bud forms a miniature floral head rather than a cluster of leaves. } \\
\text { Viewed from above, the immature bracts look like a many-pointed star. }\end{array}$ \\
\hline R2 & $\begin{array}{l}\text { Immature bud elongates } 0.5 \text { to } 2 \text { cm above the nearest leaf attached to the } \\
\text { stem. Disregard leaves attached directly to the back of the bud. }\end{array}$ \\
\hline R3 & \begin{tabular}{l} 
The immature bud elongates more than 2 cm above the nearest leaf. \\
\hline R4
\end{tabular} & $\begin{array}{l}\text { The inflorescence begins to open. When viewed directly from above, imma- } \\
\text { ture ray flowers are visible. }\end{array}$ \\
\hline R5, R5.1-R5.9 & $\begin{array}{l}\text { Beginning of flowering stage divided into substages based on the percent- } \\
\text { age of the flower head (disc florets) in bloom, e.g., R5.3 (30\% bloom), R5.8 } \\
\text { (80\% bloom). }\end{array}$ \\
\hline R6 & \begin{tabular}{l} 
Flowering is complete and the ray flowers are wilting. \\
\hline R7
\end{tabular} & $\begin{array}{l}\text { The back of the head has started to turn pale yellow. } \\
\text { The back of the head is yellow but the bracts remain green. }\end{array}$ \\
\hline R8 & Bracts become yellow and brown and physiological maturity is reached \\
\hline R9 &
\end{tabular}

Source: Schneiter et al. 2013
Sunflower Development, https://www.ag.ndsu.edu/publications/ crops/stages-of-sunflower-development/a1145.pdf. Sunflowers reach physiological maturity at the R9 stage and can be harvested once the desired seed moisture content (about 10\%) is reached. In the Sacramento Valley, for a March planting time, maturity is reached in 130 to 140 days from the planting date. For April and May plantings maturity is typically reached in 120 days. In the Imperial Valley sunflowers are typically planted in February, with 130 to 140 days to harvest from the planting date. In general, sunflower fields initiate bloom about 60 to 70 days after planting, bloom for about 10 days, and then are harvested about 60 days after bloom.

Sunflowers are in the Compositae family. The sunflower head is actually not a single flower but a flower head consisting of numerous small individual florets. The outside florets resembling petals are called ray flowers and are sterile. The numerous disk flowers in the center produce seed and normally are considered 'perfect' (having both male and female parts). However, in hybrid seed production the female lines have cytoplasmic male sterility, so they produce only female florets, enabling cross-pollination with a male line (see the sidebar on p. 4 for a description of sunflower hybrid seed production).

\section{Variety and Seed Selection}

Sunflower breeding programs for hybrid seed development are primarily driven by private seed companies. Hybrid sunflower varieties are first produced when plant breeders cross-pollinate two different inbred selection lines where each of the parents contain complimentary traits (see the sidebar for more information). The first generation of a hybridized plant cross (labeled as F1) tends to grow with more vigor and produce higher yields and oil content than the parental lines. The hybrids also display better disease resistance, self-compatibility (reducing the need for bee crosspollination), and uniformity in height, maturity, and moisture content, which facilitates harvest.

The two main types of sunflower varieties are oilseed and non-oilseed (confectionery). Oilseed varieties have a very high oil content (40 to 48 percent); they are processed into sunflower 
oil, and the resulting meal is used as a high-protein (about 25\%) animal feed. Small-seeded oil types are also used for birdseed. The confectionary types usually produce a larger black and white striped seed and are used in a variety of food products ranging from snacks to bread. Most of the oilseed sunflower hybrids planted in North America fall in the mid (55 to 75 percent) to high (greater than $80 \%$ ) oleic fatty acid content range. These edible oils are stable, with no trans fats, are naturally low in saturated fats, and resist rancidity in long-term storage. Hybrids with high linoleic acid content (the dominant type in the United States prior to 2000) produce a polyunsaturated oil, which is considered to be less healthy and not

\section{Sidebar: Hybrid Sunflower Seed Production}

Hybrid sunflower seed production is accomplished using cytoplasmic-genetic male sterility. This system uses three parent lines, an A-line, a B-line, and an R-line, as shown in the adjacent figure. The male-sterile parent line, or A-line, does not produce pollen and is therefore referred to as "female." The cause of this malesterile condition is due to a combination of male-sterile DNA in the cytoplasm's DNA and recessive fertility restoration DNA in the nuclear DNA. Cytoplasmic DNA is maternally inherited.

The female line cannot be self-pollinated (it's male-sterile). Therefore, to maintain parental seed stocks of the female line, the female line is crossed with a "maintainer" line, also referred to as the $B$-line. The maintainer line is genetically similar to the female line in its nuclear DNA, but it produces pollen because it contains male-fertile DNA in the cytoplasm's DNA. When the maintainer line is crossed with the female line, seed from the female line is harvested. This seed contains the same nuclear DNA as its parents and the maternally inherited male-sterile cytoplasm. This line is then used as the female parent for hybrid seed production and crossed with the male (restorer) line (R-lines)

For hybrid seed production, the female line (A-line) is crossed with the male R-line, since the R-line contains dominant fertility preferred by the U.S. food manufacturing industry. However, the bulk of the rest of the world produces sunflower oils high in linoleic fatty acid content. In some years, $60 \%$ of the seed production acreage is for export, with a predominance (about 90\% or higher) of high-linoleic types.

Commercial sunflower seed is virtually all proprietary and owned by companies such as NuSeed, DOW-DuPont-Pioneer, Syngenta, Limagrain, and Bayer-Monsanto, who contract with growers to produce the seed. There are no genetically modified (GMO) sunflowers currently on the market. Because the Helianthus genus is native to North America, there is concern regarding

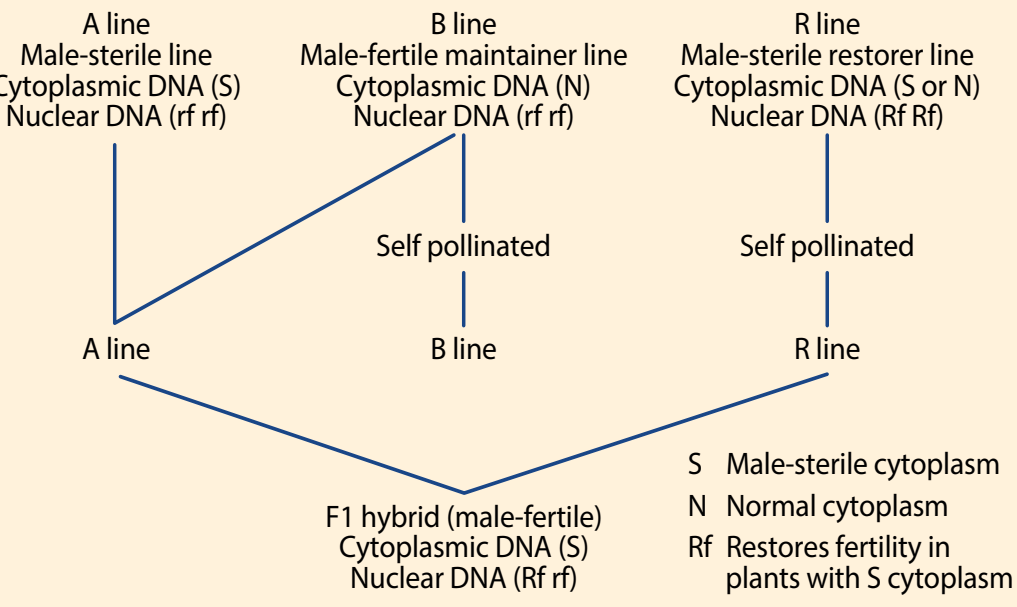

Method of hybrid sunflower seed production using naturally occurring selective breeding techniques.

restoration DNA that restores the fertility in the seed harvested from the females. While R-line restorer plants are self-fertile and produce seed, they are referred to as "males," as their purpose in hybrid production is to provide pollen to the female lines in the field. 
uncontrolled gene flow of GMO types into wild sunflowers. Herbicide-tolerant hybrids such as Clearfield with imazamox tolerance and ExpressSun with tribenuron tolerance were derived through conventional (non-GMO) breeding, using wild sunflowers that already exhibited these genetic traits.

\section{Crop Standards and Certification}

Hybrid sunflower seed production must follow strict standards to meet California state export mandates for all certified sunflower fields. These include crop rotation, weed and disease control, simultaneous bloom of male and female lines, and field isolation in time and space to ensure varietal purity (no undesired pollination crosses, including "off-types" which are other varieties that would cause genetic contamination in the hybrid crop). Standards are set by the University of California Division of Agriculture and Natural Resources California Crop Improvement Association (CCIA) and the California Department of Food and Agriculture (CDFA 2015). These standards may change, so it is important to check the CCIA website, http://ccia.ucdavis.edu/Crop_Standards_pages/Sunflower/ (CIA 2018b), for the most up-to-date information on certified hybrid sunflower seed production. To meet the standards, fields are certified by two agencies, CCIA and the county agricultural commissioner (under the jurisdiction of CDFA) in the county where the sunflower seed is produced.

CCIA inspects fields three times during the season for genetic purity, appropriate field isolation including no wild or volunteer sunflowers, and weed control. The first inspection occurs during prebloom (before R3 stage), the second during early bloom (R 5.1), and the third during mid to late bloom (R5.2 to 5.9). When "offtypes" are found, the seed companies will send in crews to rogue the fields for other varieties, to within prescribed tolerances. Any pollen-shedding females, called "shedders," will also be rogued. Additional roguing may be required if either the seed company agronomist or the CCIA inspector continue to find excessive levels of off-types, shedders, or diseased plants in the field.

CCIA inspects fields for noxious weeds that fall into two classifications: prohibited and restricted. The list of plants prohibited under the California Seed Law (2014), including seeds and propagules, are updated periodically and listed on the CCIA website (2018c). There is zero tolerance in certified seed production for either prohibited or restricted weeds in both the field and seed lots (see species in the section "Weed Control," below). CCIA may reject fields and refuse certification due to unsatisfactory appearance caused by weeds, poor growth, poor stand, disease, insect damage, and any other condition that prevents accurate inspection or creates doubt as to the identity of the variety. For noncertified seed production, restricted weeds, as well as weed seeds that are difficult to separate from sunflower seed, must be controlled and are subject to tolerance standards after harvest.

Certification standards for hybrid sunflower seed production require a 1.25-mile isolation from volunteer sunflowers, wild sunflowers, ornamental sunflowers, and sunflower fields containing a different male line. Failure to accomplish adequate isolation within the prescribed tolerances prior to bloom will subject harvested seed to a mandatory grow-out and possible rejection of seed, depending on the grow-out results for identifying seed purity. To ensure isolation during the growing season, seed companies coordinate planting of seed fields off season, using an electronic isolation map hosted by CCIA (see http://ccia.ucdavis.edu/ Crop_Isolation_Mapping). This map, however, does not maintain a comprehensive listing of wild sunflower populations, so companies will generally avoid planting in regions historically known to have large populations of wild sunflowers, such as the Sacramento Delta region and the San Joaquin Valley.

County agricultural commissioner biologists inspect sunflower hybrid seed fields twice during the season for diseases. The first occurs during prebud formation (prior to the R1 stage), when they primarily look for virus symptoms. The second field inspection is between full bloom and seed maturity (R5-R6 stages), when they inspect for a range of diseases (see the section "Diseases," below). All suspected disease samples are sent to the CDFA Plant Diagnostic Lab in Sacramento for disease identification by plant pathologists to ensure accurate and complete identification. After harvest, the county agricultural commissioner office issues a certificate that is 
attached to the batch of seed produced in their county that is used for tracking across county or state lines. This certificate is used as proof that the seed meets foreign phytosanitary requirements for diseases that can be visually observed in the field. If additional lab tests are required for an export phytosanitary certificate, the exporting county will run the tests required according to either USDA Standards (USDA website) or an import permit provided by the exporter. The exporting county is not always the same as the county of origin because seed lots are moved to different counties for export. For example, seed produced in Sutter County may be moved to Yolo County for export, but all seed is tracked as to origin, to ensure regulations are met.

\section{Land Selection}

Sunflowers grow best in deep, loamy soils with light to medium texture and good drainage. Sunflowers produced on clay soils must be managed carefully because these soils tend to remain saturated for long periods, which favors damping-off seedling diseases (especially from Pythium root rot) leading to stand losses. Avoid growing sunflowers in soils with high salinity or alkalinity, low $\mathrm{pH}$ (less than 6.5), or high boron. Although sunflowers have some

Table 2. Soil boron and salt tolerance limits of selected field crops

\begin{tabular}{|l|c|c|}
\hline Crop & Boron (B, ppm) & Threshold soil salinity ${ }^{{ }^{\prime}}$ \\
\hline alfalfa $^{2}$ & $4-6$ & $>6.0$ \\
\hline blackeye or cowpea, Vigna unguiculata & 2.5 & 4.9 \\
\hline common dry beans, Phaseolus vulgaris & $0.50-0.75$ & 1.0 \\
\hline garbanzo beans, Cicer arietinum ${ }^{2}$ & $<1-2$ & $<2.5$ \\
\hline lima beans, P. lunatus & $0.75-1.0$ & 1.5 \\
\hline sunflowers & $0.75-1.0$ & 4.8 \\
\hline tomatoes & 5.7 & 2.5 \\
\hline wheat & $0.75-1.0$ & 6.0 \\
\hline
\end{tabular}

Source: Ayers and Westcot 1994

Notes:

1. Value is the electrical conductivity of saturated soil extract, ECe, dS/m or mmho/cm, and the maximum soil salinity that does not reduce yield below that obtained under nonsaline conditions.

2. Research indicates a significant range in both B and salinity tolerance in garbanzos and a much higher salinity tolerance for some salt-tolerant alfalfa varieties than reported by Ayers and Westcot 1994. tolerance to these problem soils compared with other crops (table 2), high boron or salt levels can cause sunflower stand loss and variable height and maturity in the field. Fields must also be isolated in time and space to avoid cross-pollination with other sunflower varieties (see the Crop Standards section, above).

\section{Crop Rotation}

Crop rotation helps prevent weeds, insects, and diseases from building up in the field and controls volunteer sunflowers. Seed certification standards require that the land must not have grown sunflowers in the previous 3 years or that the land must have grown two intervening irrigated crops. Volunteer sunflowers must be controlled prior to planting to ensure seed purity. Suggested crop rotations include alfalfa, wheat, processing tomatoes, corn, and beans. For wheat, be aware of the ExpressSun variety with tolerance to tribenuron (Express), as this herbicide will not control volunteer sunflowers in wheat.

\section{Land Preparation}

Sunflowers have relatively large seeds and are less sensitive to seeding depth than smaller-seeded crops. However, at planting, they still need a well-worked seedbed that is smooth, fine (no clods), firm (but not compacted), and preferably with good soil moisture at planting, to ensure simultaneous emergence of male and female lines. It is well worth the extra effort to prepare good seedbeds. Poor and uneven seedbeds can affect the rate of seed germination, resulting in a poor "nick" (simultaneous flowering of male and female lines) and subsequent yield losses due to poor pollination. For land preparation for planting, primary tillage operations depend on field conditions (such as soil type and degree of compaction) and irrigation practice (subsurface drip versus furrow). On sandier soils with minimal soil compaction, beds can be reshaped after disking in the previous crop residue. However, soils with more clay, as tend to occur in the Sacramento Valley, have more problems with soil compaction and often require more extensive field preparation.

Field preparation usually begins with uniformly ripping or chiseling to break up compacted soils. Furrow-irrigated fields are ripped to a depth of 18 inches, whereas fields with subsurface drip 
systems are chiseled in the furrows, to a depth of 12 inches, taking care not to destroy the drip system. Afterwards, fields are disked and ring-rolled in one operation in the fall twice to incorporate the previous crop residue and break dirt clods, taking care not to go too deep and disrupt any subsurface drip systems. A finishing disk further breaks clods and makes a fine seed bed, followed by a GPS drag scraper (finishing scraper) to smooth the ground and level fields. Afterward, beds are formed using bed-making equipment, with the bed size depending on the sunflower variety and production capability and also on the growers' equipment preference. Subsurface drip fields are mapped with GPS technology so that the beds are always formed over the buried drip tape. Bed size will vary from single-seed rows on 30 -inch beds to double seed rows on 60 -inch beds, and sometimes three seed rows on 80 -inch beds. The minimum soil temperature at planting is $50^{\circ} \mathrm{F}$.

Weeds that have germinated during the wintertime must be controlled prior to planting, either by cultivation or by an herbicide application, such as glyphosate (Roundup). Fields are cultivated for weed control and to incorporate herbicides prior to planting (January-February in the Imperial Valley or March to May in the Sacramento Valley).

\section{Seeding Rate and Timing}

In the Sacramento Valley, sunflowers are planted from March to May in two or three planting dates, depending on rainfall and how early the fields can be worked and planted. In the Imperial Valley, seed is generally planted in mid-January to mid-February. All seeding rates are calibrated to establish approximately 22,000 to 24,000 seeds per acre for females and 18,000 to 22,000 seeds per acre for males, depending on the parent line. At planting 17 to 25 percent of the plants are typically male, with the ratio of females to males depending on the hybrid being produced. Field row ratios of 6:2, 8:2, and 10:2 (female:male) row configurations can be used for hybrid seed production. The configuration depends on the pollen production of the male lines and the honey bee attractiveness of the female parent, and will be specified by the seed company.
Calculate the planting rate, based on the recommended final stand and the germination rate of the seed being used. The calculated rate should be increased by about 5 to 10 percent to compensate for germination percentage. For example, the pounds of female seed needed for an 80-acre field with a 10:2 female to male ratio ( 10 female rows divided by 12 rows total, or 10/12), with 6,000 kernels (seeds) per pound with a 95 percent germination is calculated as follows.

Female seed required:

$$
\begin{aligned}
& 80 \text {-acre field } \times 10 / 12 \text { female-to-male-ratio }= \\
& 66.7 \text { acres planted to female seed }
\end{aligned}
$$

Required 24,000 plants/acre $\times 66.7$ acres $\div 6,000$ seeds per pound $=266$ total pounds of seed

Correct for $95 \%$ germination: $266 \div 0.95=280$ pounds of female seed required (4.2 pounds of seed per planted acre)

To calculate the target spacing between plants (inches): plant 4.2 pounds of seed per planted acre to attain 24,000 plants/acre stand (above)

4.2 pounds/acre $\times 6,000$ seeds/pound $=25,200$ seeds/acre 1 acre $=17,424$ linear feet (per 30-inch rows)

\section{7,424 feet/acre $\div 25,200$ seeds/acre $=0.691$ feet $/$ seed} or 8.3 inches between plants.

Sunflower planting seed should be treated with fungicides to reduce seedling disease losses from Pythium root rot and downy mildew (Plasmopara sp.) (see the section "Diseases," below). Handle sunflower seed bags carefully. Walking on bags or throwing and dropping them can cause internal (cryptic) seed injury, resulting in poor germination. Leaving bags out in the sun can also reduce seed germination.

Different planting times are frequently required for the male and female lines to ensure a good nick, the simultaneous bloom of males and females for good cross-pollination. Male and female plantings are timed such that the males bloom about 3 to 5 days before the females. Depending on the flowering days of each line, 
the males may be planted first, then the female line is planted up to a week later. Sometimes the female line is planted first, or there may be two different planting dates for the male lines, depending on the longevity of bloom of the male parent. Seeds planted into moist soil begin to emerge in 5 to 7 days, depending on soil temperature. Companies contracting sunflower hybrid seed production provide the seed and specify planting rates and timing. Growers are not charged for the seed, as it is considered the intellectual property of the seed company, and is furnished as part of the contract for seed production.

\section{Pollination}

Overlap in flowering between male and female lines (a good nick) is needed in hybrid sunflower seed production to ensure good pollination by pollinators and seed set. Honey bees (Apis mellifera) are used for moving pollen between the male and female parent lines at a stocking rate of 1.5-2 hives per acre. Growers commonly contract with beekeepers for hives at a current cost of $\$ 40$ to $\$ 50$ per hive. Hives should be set around the fields when the male plants begin to flower (and always before females bloom) to ensure that the bees stay in the field. Insecticide applications for pest control should be made before the delivery of bees to the field or early in the morning before most bees are actively foraging.

Male lines are usually highly branched and have more flowers to maximize pollen production and pollination, compared to the single female flower. Poor seed set can occur when simultaneous bloom doesn't occur, if the female parent is unattractive to bees (e.g. low nectar production), if the male parent line is a poor pollen producer, or if weather conditions are unfavorable for pollen production and honey bee activity. High temperatures (above $80^{\circ} \mathrm{F}$ ) can reduce the number of pollen grains per flower in sunflower; however, no differences in pollen germination rates at an upper limit of $88^{\circ} \mathrm{F}$ have been observed, indicating pollen viability is resilient. Honey bee activity and subsequent seed set can be reduced by wind or if it is too hot or too cold. Honey bee activity ceases below $55^{\circ} \mathrm{F}$ and above $95^{\circ} \mathrm{F}$. Seed set can also be less in the center rows when wide passes of 12 or more female rows are planted due to a lack of honey bee foraging activity. Symptoms of poor pollination include empty or underdeveloped hulls.

Native bees, including a digger bee (Diadasia sp.) and longhorned digger bees (Melissodes sp. and Svastra sp.), sometimes referred to as 'sunflower' bees, primarily collect pollen. Honey bees either forage for nectar or pollen, but not both. Native bees often jostle honey bees around in sunflower fields, causing honey bees to disperse more, making them better pollinators. Some species of native bees are solitary and nest in the ground and can be encouraged through on-farm insectary plantings (see the UC IPM Website, http://ipm.ucanr.edu/mitigation/insectary_plants.html).

Chop and destroy the male plants once the female line is finished flowering and has set seed (R6 stage) to prevent seed contamination of the female line at harvest. In addition, destroying the male rows before they set seed also helps reduce volunteer sunflowers that can be difficult to control in subsequent crops, especially for herbicide tolerant sunflowers, like Clearfield or ExpressSun.

\section{SOIL FERTILITY AND FERTILIZERS}

\section{Soil Sampling}

Prior to planting, sample the soil from 0 to 6 inches deep to determine the likelihood of crop response to phosphorus (P), potassium $(\mathrm{K})$ and zinc $(\mathrm{Zn})$ fertilizer. If soils are deficient in these nutrients, sunflowers are likely to be responsive to them. If yield differences existed within a field for the previous crop, sample and analyze these areas separately by taking 12 to 15 cores in each problem area from 0 to 6 inches deep and mixing them together to make up a composite sample. Separate samples should also be taken from areas of the field with different soil types that could affect nutrient availability.

The soil $\mathrm{pH}$ should be from 6.0 to 8.0 for good sunflower production. Although sunflowers appear to tolerate soils with $\mathrm{pH}$ as low as 5.5, consider liming if the $\mathrm{pH}$ is below 6.0 to improve nutrient availability in the soil. Areas of known or suspected high salinity or boron should be sampled at depths of 0 to 6, 6 to 12 , and 12 to 24 inches if there is reason to suspect toxicity problems. 
Knowledge of field history and past nutrient deficiencies (such as sulfur) or toxicities (such as salts or boron) should be taken into consideration before planting sunflowers.

\section{Nitrogen}

Sunflowers have a deep taproot (up to 6 feet) and are good scavengers of nitrogen $(\mathrm{N})$. Some $\mathrm{N}$ will be available from the previous crop, long-term fertilization practices, and $\mathrm{N}$ release from soil organic matter. For example, more $\mathrm{N}$ will be available in the soil after a tomato crop, than after corn or wheat. If $\mathrm{N}$ is deficient, the older sunflower leaves will turn uniformly pale green to yellow, plant growth will be reduced, flowers may not develop, and heads will fill poorly.

Table 3. Suggested nitrogen $(\mathrm{N})$ fertilizer rates per acre for sunflower hybrid seed based on nitrate-N levels in the top 24-inch soil depth just prior to the planned sidedressing

\begin{tabular}{|c|c|c|}
\hline $\begin{array}{c}\text { Average ppm } \\
\mathrm{NO}_{3}-\mathbf{N} \text { in top 24 } \\
\text { in. of soil }\end{array}$ & $\begin{array}{c}\text { Average } \mathrm{NO}_{3}-\mathbf{N} \\
\text { in top 24 in. of } \\
\text { soil (lb)* }\end{array}$ & $\begin{array}{c}\text { Fertilizer } \mathbf{N} \\
\text { (lb/ac) }\end{array}$ \\
\hline $0-2$ & $0-16$ & 100 \\
\hline $2.1-4$ & $17-32$ & 80 \\
\hline $4.1-6$ & $33-48$ & 60 \\
\hline $6.1-8$ & $49-64$ & 40 \\
\hline $8.1-10$ & $65-80$ & 20 \\
\hline$>10$ & $>80$ & 0 \\
\hline
\end{tabular}

Source: Hergert and Schild 2013

Note: *Pounds of potentially available nitrate-N per acre in each foot of soil can be estimated by multiplying parts per million of nitrate-N by a factor of 4 (or 8 for the top 2 feet).

As a starting point for determining $\mathrm{N}$ needs in sunflowers, the seed (the achene, including the kernel and the hull, or shell) has an average $\mathrm{N}$ content of 3.7 percent. For a yield of 1,400 pounds per acre, the seed will need at least 52 pounds of $\mathrm{N}$ per planted acre to account for crop removal. An additional 25 pounds of $\mathrm{N}$ per acre will be needed for the plant $(68 \%$ of the total $\mathrm{N}$ in the plant is in the seed, the rest is in the plant). Adding 25 percent more $\mathrm{N}$ for male acreage

(requiring the same $\mathrm{N}$ rate and timing for ensuring simultaneous bloom with female lines and good pollination), the total $\mathrm{N}$ needed by a sunflower crop producing 1,400 pounds per acre yield is approximately 100 pounds of $\mathrm{N}$ per acre, with yield calculated on a whole-acre basis. Fertilizer trials in sunflowers have generally not shown yield benefits at $\mathrm{N}$ application rates exceeding 100 to 150 pounds N/acre.
To ensure good hybrid sunflower seed production, fertilization begins with a starter fertilizer of 8-24-6 with 1-2\% Zn band-applied during planting, 2 inches below and 2 inches to the side of the seed row. Apply about 100 pounds of dry fertilizer or 10 gallons of liquid fertilizer of similar analysis per acre. The starter fertilizer is particularly important for spring plantings with cooler soil temperatures, when phosphorus and zinc are less available. Exercise particular care with starter fertilizer placement in order to avoid salt damage or ammonia toxicity to the germinating seed. Do not use urea or diammonium phosphate, either 18-46-0 or 16-48-0. Do not place any fertilizer in direct contact with the seed. As a general rule, a monoammonium phosphate (e.g., dry 11-52-0 or liquid 10-34-0) is the preferred base fertilizer and should be placed no closer than about 2 inches to the side and about 2 inches below the sunflower seed.

At layby, when the plants are about 12 inches tall, fertilize the fields with $\mathrm{N}$ so that it is readily available for rapid plant growth and development. Prior to the $\mathrm{N}$ application, residual $\mathrm{N}$ levels in the soil should be determined about 10 to 15 days prior to the planned side-dressing. This allows for the rate of applied $\mathrm{N}$ to be based on the available nitrate- $\mathrm{N}$ in the top 24 inches of the soil (table 3 ). Take soil samples ( 8 to 12 cores per sample) from 0 to 6 inches, 6 to 12 inches, and 12 to 24 inches deep at 2 to 3 locations in each field, as described in Geisseler and Horwath (2016), and request analysis for nitrate-N. For furrow-irrigated systems, $\mathrm{N}$ should be side-dressed (injected) during a cultivation for weed control, with aqua ammonia or a similar $\mathrm{N}$ fertilizer. If using subsurface drip, start injecting $\mathrm{N}$ in the drip line (using, for example, UAN 32) when the plants are about 12 inches tall and continue until the sunflowers begin to head out (R1 to R2 stage).

Nitrogen rates can also be reduced somewhat if the irrigation water contains high nitrate levels. Calculate the number of pounds of $\mathrm{N}$ per acre-foot of irrigation water by multiplying the parts per million (ppm) nitrate- $\mathrm{N}$ in the irrigation water by the factor 2.72 . Have your water tested, because irrigation water sources vary considerably in nitrate- $\mathrm{N}$ concentration. Excess $\mathrm{N}$ applications may delay flowering, leading to yield and quality reductions. 


\section{Phosphorus}

Phosphorus (P) can be especially important for sunflower production in California due to the relatively early planting dates and cooler soil temperatures that reduce P solubility and uptake. Phosphorus is particularly important in the early stages of plant growth because it promotes the development of extensive root systems and vigorous seedlings, which also helps the plants outcompete weeds. A phosphorus deficiency is characterized by slow plant growth, poor tap root development, thin stems, and older leaves that turn yellow and drop prematurely, while the new leaves are small and dark green.

Table 4. Phosphorus recommendations for sunflower seed production

\begin{tabular}{|l|c|c|c|c|c|}
\hline \multirow{2}{*}{ Soil test } & \multicolumn{5}{c|}{ Phosphorus (ppm) } \\
\cline { 2 - 6 } & Very low & Low & Moderate & High & Very high \\
\hline Bray \#1-P & $0-5$ & $6-10$ & $11-15$ & $16-20$ & $21+$ \\
\hline Olsen $\mathrm{HCO}_{3}-\mathrm{P}$ & $0-3$ & $4-7$ & $8-11$ & $12-15$ & $16+$ \\
\hline $\begin{array}{l}\text { Yield goal (Ib/ } \\
\text { ac) }\end{array}$ & \multicolumn{7}{|c|}{ Application rate (lb $\left.\mathbf{P}_{2} \mathbf{O}_{5} / \mathbf{a c}\right)$} \\
\hline 800 & 15 & 10 & 5 & 0 & 0 \\
\hline 1,200 & 25 & 20 & 10 & 5 & 0 \\
\hline 1,600 & 35 & 25 & 20 & 15 & 10 \\
\hline 2,000 & 40 & 30 & 25 & 20 & 15 \\
\hline
\end{tabular}

Table 5. Potassium recommendations for sunflower seed production

\begin{tabular}{|l|c|c|c|}
\hline \multirow{2}{*}{ Soil test } & \multicolumn{3}{|c|}{ Potassium (ppm) } \\
\cline { 2 - 4 } & Low & Medium & Adequate \\
\hline Yield goal (lb/ac) & $0-40$ & $41-80$ & $81-120+$ \\
\hline 800 & \multicolumn{3}{|c|}{ Application rate (lb K $/$ /ac) } \\
\hline 1,200 & 10 & 5 & 0 \\
\hline 1,600 & 15 & 10 & 0 \\
\hline 2,000 & 20 & 15 & 0 \\
\hline
\end{tabular}

If a representative soil test prior to planting indicates a $P$ deficiency, apply a starter fertilizer at the rate indicated in table 4 as pounds of $\mathrm{P}_{2} \mathrm{O}_{5}$ per acre. The soil test using the Olsen bicarbonate $\left(\mathrm{HCO}_{3}-\mathrm{P}\right)$ extract should be used on soils with a $\mathrm{pH}$ of 6.5 or greater, while the Bray \#1-P extract should be used for soils with a $\mathrm{pH}$ less than 6.5. Soil tests showing very low and low extractable $\mathrm{P}$ levels would be expected to show a yield response to $\mathrm{P}$ fertilization. Crops grown in soils that have test levels in the moderate range are less likely to respond to $\mathrm{P}$ fertilizer applications.

\section{Potassium}

Potassium (K) is essential for translocation of sugars, starch formation, and for regulating the opening and closing of stomata, which helps water use efficiency. Potassium additionally promotes root growth, produces larger, more uniformly distributed xylem vessels throughout the root system, and increases plant resistance to diseases. Sunflowers also need relatively large amounts of $\mathrm{K}$ for stalk and tissue strength, since it is a tall plant. When $\mathrm{K}$ is limiting in sunflowers, deficiencies include smaller leaves, yellowing and necrosis of the lower leaves, stunting, and thinner stems that make the plant more susceptible to lodging.

If a representative soil test indicates a $\mathrm{K}$ deficiency, correct it using a starter fertilizer containing $\mathrm{K}$ at the rate indicated in table 5 as pounds of $\mathrm{K}_{2} \mathrm{O}$ per acre. Soil test (ammonium acetateexchangeable $\mathrm{K}$ ) results that fall in the low range indicate that plants should respond to $\mathrm{K}$ fertilization; test levels in the medium range indicate that the plants are less likely to respond to $\mathrm{K}$ fertilization. Few California soils in sunflower growing areas have shown yield limiting $\mathrm{K}$ deficiencies; sandy soils are the most likely to show $\mathrm{K}$ fertilizer responses.

\section{Sulfur}

Sulfur (S) deficiency, though rarely observed in sunflowers, is characterized by slow growth and overall uniform light green color of the plant. It is generally only observed once every 5 to 7 years, and may occur only after high rainfall, prolonged wet soil conditions, and cooler soil temperatures from January to March, especially in wheat. In the Sacramento Valley, some soils may show 
temporary deficiency of $S$, and most irrigation water contains little or no sulfur. Fertilizers such as ammonium sulfate, a common source of $S$ in the past, are no longer being used as commonly as non-S-bearing aqua ammonia and other high-analysis fertilizers and therefore $S$ deficiencies might occasionally occur.

Broadcast and incorporate elemental S into S-deficient soils at a rate of 50 to 100 pounds of S per acre to provide a correction that will last several years. Elemental S (90 to $95 \%$ S) is best applied in the fall when the fields are bedded up to allow time for oxidation to sulfate-S, the form used by plants. The time necessary to oxidize elemental S depends on soil temperature and moisture, as well as on the size of the particles applied. Particle size may cause the timeline to change from a few weeks (small particles) to several months (large particles) before the applied elemental S becomes effective. Other materials such as gypsum (calcium sulfate), which is about $17 \% \mathrm{~S}$, provide the readily available sulfate form of $\mathrm{S}$ and can also be used. These materials should be applied at a rate that supplies about 25 to 50 pounds of S per acre and should be incorporated into the top 2 to 3 inches of soil to be most effective.

\section{Zinc}

Zinc (Zn) deficient soils (below 0.5 ppm DTPA-extractable Zn) may occur on soils low in organic matter, calcareous, high-pH soils, or on newly leveled land that required extensive soil cuts and fills. Zinc-deficient plants are stunted and have distorted upper leaves with interveinal chlorosis that leads to leaf dieback. The potential for sunflowers to respond to $\mathrm{Zn}$ when applied to $\mathrm{Zn}$-deficient soils is small and unlikely compared with other crops such as beans.

The best way to diagnose a $\mathrm{Zn}$ status in a field is to perform soil tests before planting. The most effective application of $\mathrm{Zn}$ is a mixed fertilizer containing $\mathrm{Zn}$ at 1 to 3 pounds per acre in the starter fertilizer (or 1 to $2 \% \mathrm{Zn}$ ). In fields with severe $\mathrm{Zn}$ deficiency, apply a correction that will last for several years by incorporating zinc sulfate ( 35 to $36 \% \mathrm{Zn}$ ) into the top 6 inches of soil at a rate of 10 to 20 pounds of $\mathrm{Zn}$ per acre if the soil $\mathrm{pH}$ is less than 7.0. For soils with a $\mathrm{pH}$ greater than 7.0, apply zinc sulfate a rate of 20 to 30 pounds of $\mathrm{Zn}$ per acre.

\section{Boron}

Boron (B) deficiency in sunflower production is most likely to occur in sandy soils common on the east side of the San Joaquin Valley, but it can occur in other locations where soils are inherently low in B and the irrigation water supplies no B. Boron deficiency symptoms include chlorosis and death of young leaves, dead growing points, and distorted flower development.

Boron toxicity is likely if sunflowers are grown in high-B soils, common on the west side of the San Joaquin Valley, parts of Yolo County, and several other areas in California. Well water with high $B$ levels can also be sources of B toxicity for sunflower. Symptoms include yellowing of the leaf tips, interveinal chlorosis, and progressive scorching or death of the leaf margins. Sunflowers are semitolerant to B toxicity compared with other crops such as beans (see table 2).

A narrow range exists between deficiency and toxicity for boron sensitive crops and too much B often reduces yields. Average boron concentrations in the youngest fully mature leaves can be used to estimate plant B status: deficient ( $<15$ ppm B), sufficient (20 to 50 ppm B), high (50 to $100 \mathrm{ppm} \mathrm{B}$ ), and excessive or toxic (over 100 ppm boron).

The recommendation for soil applications of B is 0.5 to 1.0 pounds per acre, while the suggested rate for foliar application is 0.1 pound of $B$ per acre mixed in 30 gallons of water. The boron fertilizer used most frequently is sodium borate, which ranges from 10 to 20 percent boron. Solubor is a trade name for sodium borate that is 20.5 percent boron. This fine-granular material is commonly applied as a foliar spray.

\section{IRRIGATION MANAGEMENT}

Hybrid sunflower seed production requires good irrigation management practices to obtain optimal yields and high quality seed. Sunflowers have a deep taproot (5- 6-feet) and are good scavengers of water, but most of the water extraction occurs in the first 3 feet of soil and they need water to sustain high yields. The irrigation frequency will depend on the planting 
date, rainfall, water-holding capacity of the soil, crop water use (evapotranspiration of the crop, or $\mathrm{ET}_{\mathrm{c}}$ ), and region or climate zone. Sunflowers grown in the Sacramento Valley are in climate zones 12 and 14; those in the Imperial Valley are in zone 18, see the CIMIS Reference Evapotranspiration map, https://www.jpl.nasa.gov/edu/ images/activities/etozonemap.jpg.

$\mathrm{The}_{\mathrm{ET}}$ in inches per day for sunflowers grown in the Sacramento Valley with March, April, and May planting dates are shown in table 6. The $\mathrm{ET}_{\mathrm{c}}$ for sunflowers grown in the Imperial Valley for early and mid-February planting dates are shown in table 7. Overall, the cumulative seasonal $\mathrm{ET}_{\mathrm{c}}$ total ranges from about 22

Table 6. Average crop evapotranspiration (ET) in inches per day for sunflowers planted on March 15, April 16, and May 16, for Zones 12 and 14 in the Sacramento Valley, for both furrow and subsurface drip systems.

\begin{tabular}{|c|c|c|c|c|c|c|}
\hline \multicolumn{7}{|c|}{ Sunflower ET (in./day) } \\
\hline \multirow[b]{2}{*}{ Planting date } & \multicolumn{3}{|c|}{ Zone 12} & \multicolumn{3}{|c|}{ Zone 14} \\
\hline & March 15 & April 16 & May 16 & March 15 & April 16 & May 16 \\
\hline March 15-31 & 0.02 & - & - & 0.03 & - & - \\
\hline April 1-15 & 0.03 & - & - & 0.04 & - & - \\
\hline April 16-30 & 0.10 & 0.04 & - & 0.10 & 0.04 & - \\
\hline May 1-15 & 0.19 & 0.05 & - & 0.19 & 0.05 & - \\
\hline May 16-31 & 0.26 & 0.15 & 0.05 & 0.26 & 0.15 & 0.05 \\
\hline June 1-15 & 0.27 & 0.26 & 0.07 & 0.27 & 0.26 & 0.07 \\
\hline Jun 16-30 & 0.29 & 0.29 & 0.17 & 0.29 & 0.29 & 0.18 \\
\hline July $1-15$ & 0.26 & 0.29 & 0.28 & 0.27 & 0.31 & 0.29 \\
\hline July 16-31 & 0.15 & 0.26 & 0.29 & 0.17 & 0.28 & 0.31 \\
\hline August 1-15 & - & 0.15 & 0.27 & & 0.16 & 0.29 \\
\hline August 16-31 & - & - & 0.22 & - & - & 0.24 \\
\hline Sep 1-15 & - & - & 0.12 & - & - & 0.13 \\
\hline Seasonal total (in.) & 24.15 & 22.80 & 22.57 & 24.63 & 23.65 & 24.01 \\
\hline
\end{tabular}

Source: Snyder et al. 2014.

Note: CIMIS (1999) reference evapotranspiration map, https://www.jpl.nasa.gov/edu/images/activities/etozonemap.jpg. to 24 inches, depending on the zone and planting date. These crop requirements (tables 6 and 7) are the starting point for irrigation applications, which are adjusted upwards from 5 to $25 \%$, based on the limitations of distribution uniformity and inefficiencies of the irrigation system. These tables can be used for both furrow and drip irrigation, as the charts for both are very similar, and most importantly, the peak period $\mathrm{ET}_{c}$ are identical. The sunflower crop coefficients used were developed by Snyder et al. (2014).

\section{Irrigation Scheduling}

Sunflowers are often seeded into moisture from rainfall, especially in earlier spring plantings for the Sacramento Valley. For later plantings, fields are often preirrigated via solid-set sprinklers and then seeds are planted into moisture. Sometimes fields are planted dry and sprinkled up until roots reach the water from the drip line, or moisture from furrow irrigation. Planting dry and irrigating via furrow-irrigation is not recommended because this often results in

Table 7. Average crop evapotranspiration (ET) in inches per day for sunflowers planted on February 1 and 15 for Zone 18 in the Imperial Valley, for both furrow and subsurface drip systems

\begin{tabular}{|l|l|l|l|}
\hline \multicolumn{2}{|l}{ February 1} & \multicolumn{2}{l}{} \\
\hline Feb 1-15 & 0.02 & - & - \\
\hline Feb 16-28 & 0.03 & Feb 15-28 & 0.02 \\
\hline Mar 1-15 & 0.08 & Mar 1-15 & 0.03 \\
\hline Mar 16-31 & 0.17 & Mar 16-31 & 0.10 \\
\hline Apr 1-15 & 0.23 & Apr 1-15 & 0.20 \\
\hline Apr 16-30 & 0.26 & Apr 16-30 & 0.26 \\
\hline May 1-15 & 0.30 & May 1-15 & 0.30 \\
\hline May 16-31 & 0.26 & May 16-31 & 0.32 \\
\hline June 1-10 & 0.18 & June 1-15 & 0.26 \\
\hline- & - & June 16-25 & 0.18 \\
\hline Seasonal total (in.) & 22.40 & Seasonal total (in.) & 24.78 \\
\hline
\end{tabular}

Source: Snyder et al. 2014. 
weed problems and seedling damping-off diseases. The amount of water needed from sprinklers to establish a crop from seed is 2 to 6 inches for the Sacramento Valley in two to four applications. About 4 to 6 inches is needed for stand establishment in the low desert, depending on rainfall. The sprinkler water is part of the season $\mathrm{ET}_{\mathrm{c}^{\prime}}$ so if you are estimating water use at 24 inches, the 2 to 6 inches would be part of this. For example, for Zone 14 for a May planting date (see table 6), about 4 inches would come from the sprinklers and 20 inches would come from SDI or surface applications.

Irrigation management of sunflowers requires appropriate irrigation scheduling (determining when and how much to irrigate) and good irrigation management practices to deliver the desired amount of water efficiently and uniformly. The most practical way to describe a good irrigation of sunflowers is frequent but light. Canopy color differences are readily seen in fields or sections of fields. Well-irrigated sunflowers are dark green, which turn a lighter bluish-green as water stress develops. Sunflowers are fairly heat tolerant, but watch for excessive heat waves that can injure the crop, especially during the early bud stage. Be prepared with good soil moisture going into these heat waves; do not wait to observe plant stress, to avoid crop injury.

\section{Furrow (Flood) Irrigation}

Furrow-irrigated sunflowers require irrigation every 8 to 10 days, depending on the soil type, with sandier soils requiring morefrequent irrigation. Furrow irrigation systems are not as efficient as subsurface drip systems due to water losses from tailwater runoff, deep percolation from ditch seepage, and overirrigation on all or parts of the field. Once water passes below the root zone of the sunflowers, it is lost. In general, furrow systems are about 75 percent efficient. Therefore, the irrigation amount for furrow irrigated systems should be adjusted as follows:

\section{Irrigation amount $=$}

(Crop evapotranspiration $\div$ Irrigation efficiency) $\times 100$
For example, if the weekly sunflower $\mathrm{ET}_{\mathrm{c}}$ is 1.8 inches and the furrow irrigation system application efficiency is 75 percent efficient, 2.4 inches of water would need to be applied:

$$
(1.8 \text { inches } \div 75) \times 100=2.4 \text { inches }
$$

Furrow irrigation can easily saturate high clay soils, leading to anaerobic conditions (oxygen starved) that will favor fungal pathogens, such as Pythium, Phytophthora, and downy mildew. When irrigating clay soils, use a wide bed with furrows formed on 60 -inch or 80 -inch centers as opposed to 30 -inch centers. Irrigation runs in clay soils should be 600 to 800 feet long, if possible, but never longer than 1,200 feet. This system leaves an area between the rows on the wider beds unsaturated, maintaining good aeration in the soil for root growth.

Furrow irrigation must be performed carefully to get good moisture penetration to the entire root system without saturating soils. On 30-inch beds, some growers may irrigate every other row, alternating the furrows irrigated during each irrigation, to manage water better on heavy soils or to irrigate the field faster before a heat spell. Soils with a high level of silt absorb moisture well after a cultivation, but once they have been irrigated a couple of times, they seal and become almost impervious to water penetration. Time cultivations carefully to allow equipment to access rows to open up the soil, but before plants mature and close rows.

\section{Subsurface Drip Irrigation}

Subsurface drip irrigation (SDI) systems irrigate uniformly and efficiently ( 85 to 95 percent distribution uniformity), with frequent small irrigation amounts matching crop water use (ET). Using SDI also has the advantage of reducing weed growth, since the soil surface is not wetted. In general, two rows of sunflowers are planted on a 60-inch bed with one drip line in the center. Most SDI lines are placed 8 to 10 inches deep, allowing for good soil moisture for the crop, while at the same time allowing for significant bed work without damaging the drip lines and easy access for repairs. SDI irrigation amounts should be adjusted for inefficiencies, as with 
furrow irrigation, with adjustments of 85 to 95 percent (5 to 15 percent greater than $\mathrm{ET}_{\mathrm{c}}$ ).

Rodents, especially gophers, are a major problem in SDI systems because they chew the drip tape underground, resulting in leaks that are often difficult to find and repair. Voles also chew on the drip tape, especially when they scavenge for residual sunflower seeds after harvest, where cracking soils allow them access to the drip lines. Monitor and control these pests to prevent damage to irrigation systems (see the Vertebrate Pest Control Handbook, http:// vpcrac.org/about/vertebrate-pest-handbook/ ).

\section{Soil Moisture Monitoring}

Although soil moisture can be assessed by using the "look and feel" method, soil moisture sensors can provide more accurate information. There are many sensor options available to growers, including tensiometers and gypsum blocks, that are accurate and relatively easy to use and inexpensive. Tensiometers indicate soil moisture levels by measuring the soil moisture tension, or how strongly water is held onto soil particles. The higher the tension the more difficult it is for plant roots to extract water from the soil. Therefore, low soil moisture tension indicates moist soil, and high soil moisture tension indicates dry soil. Gypsum blocks buried in the soil measure the electrical resistance of water, which can be converted into a soil moisture tension value. Soil moisture tension is usually expressed in centibars (cb).

Soil moisture sensors must be installed in areas that are representative of the field; that is, the site must have a soil type that is typical of the field and needs to receive full irrigation coverage. Sensors should be installed to the depth of the active root water uptake zone, which for sunflowers would be 4 feet. Monitor soil moisture at 1 foot, 2 feet, 3 feet, and 4 -feet deep to determine when to irrigate and to ascertain the depth or adequacy of an irrigation. It may also be useful to monitor at 5 feet to determine whether excess irrigation water is being applied, causing water to percolate past the sunflowers' 4 - to 5 -foot rooting depth.

The threshold level for soil moisture in the root zone for sunflowers and irrigation needs depend on soil type, irrigation system (furrow or drip), growth stage, and amount of deep moisture in the soil profile. General guidelines for soil moisture monitoring can be given based on limited experience with sunflower production in clay loam soils in the low desert of California. For heavy soils, the upper limit for soil moisture depletion in the top 2 feet of the root zone is 90 to $120 \mathrm{cb}$. Irrigation should be applied when soil moisture content reaches this threshold level. If soil moisture is depleted beyond this level, the crop will be under stress. However, roots can extend beyond 4 feet and this threshold could be reached and the crop may not show signs of stress if there is moisture in the deeper soil profile or a shallow water table available up to 6 to 8 feet below the soil surface. In experiments conducted at the UC Desert Research and Extension Center from 2016 to 2018, sunflower plots that were subjected to 60 percent deficit irrigation practices showed no stress and yields were not affected by the reduced water applications due to the presence of a shallow water table 6 to 8 feet below the soil surface.

\section{INTEGRATED PEST MANAGEMENT}

A number of weeds, insects and mites, and diseases of sunflowers must be monitored and controlled through a combination of management practices. This includes using certified disease-free seed, seed treatments, crop rotation, and pesticides when needed. This section focuses on weeds, pests, and diseases known to be prevalent in California that can cause problems in sunflower seed production and marketing. More information on pests and diseases in sunflower can be found in Harveson et al. 2016 and Berglund 2007.

\section{Insects}

In some years, soil pests that live at or below the soil line, such as variegated cutworm (Peridroma saucia, fig. 5), wireworms (Limonius spp.,

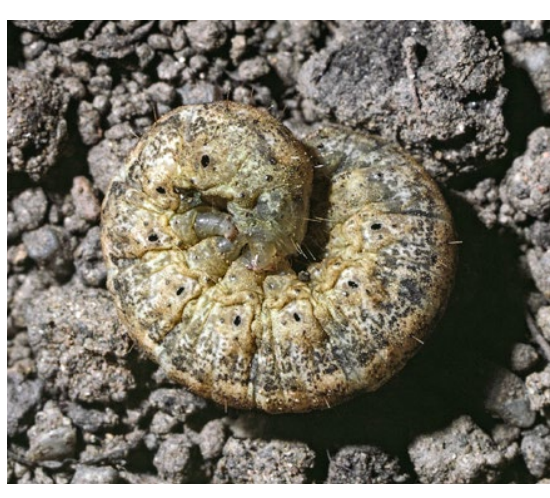

Figure 5. Variegated cutworm, Peridroma saucia. Photo: UC IPM. 
fig. 6), and seed corn maggot (Delia platura, fig. 7), can seriously damage seedlings and cause significant stand losses. These pests tend to be sporadic in time and space; they tend to be more troublesome in wet years when weed vegetation is heavy, and they have a patchy distribution in fields. They are often problematic in the same field year after year, so monitoring and being familiar with the history of the field is important for managing these pests in crop rotations. Use of insecticide seed treatments, such as Cruiser 5FS (thiamethoxam) will help control early-season soil-dwelling pests.

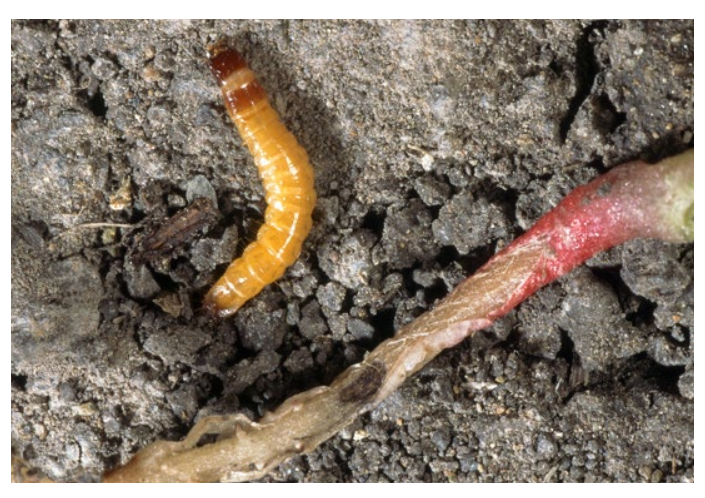

Figure 6. Wireworms, Limonius spp. Photo: UC IPM.

\section{Sunflower Moth}

Sunflower moth, also known as sunflower head moth (Homoeosoma electellum, figs. 8 and 9), is the most serious pest of sunflower in California and other U.S. sunflowergrowing states. The adult sunflower moth is grayish, $3 / 8$ inches long, and rests with wings clasped tightly to the body, giving it a slender cigar shape (see fig. 8). Eggs are difficult to find because they are usually laid

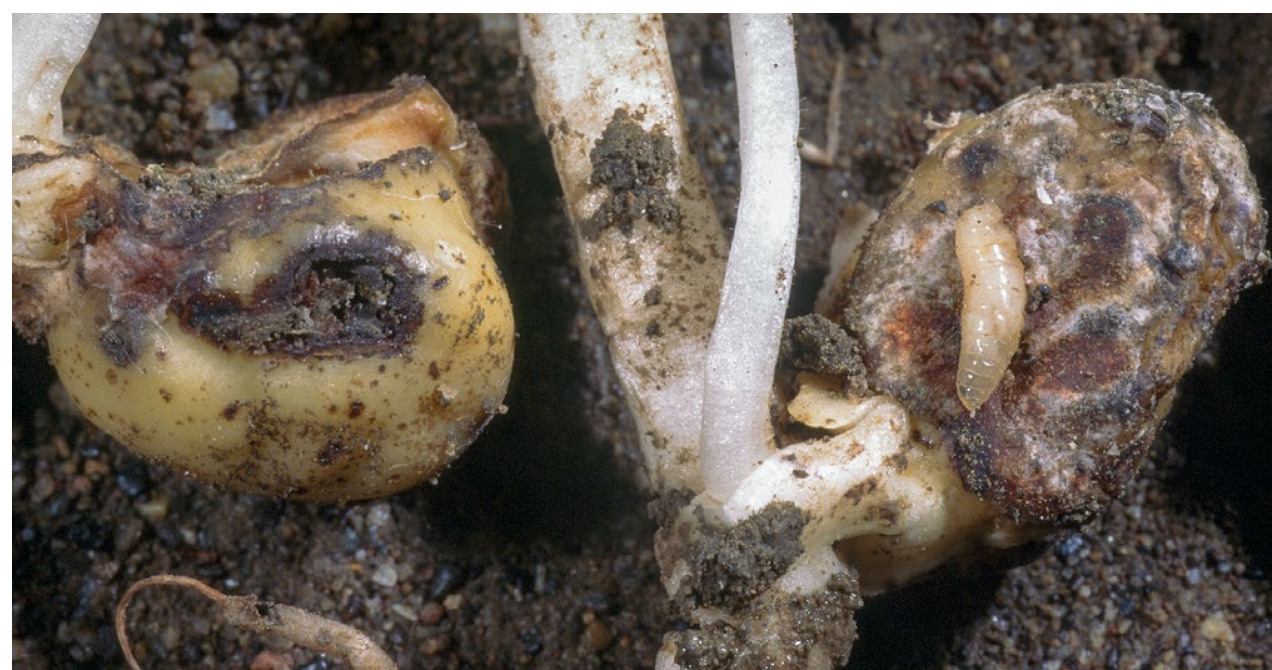

Figure 7. Seed corn maggot, Delia platura. Photo: UC IPM.

at the base of florets in the flower head. The newly hatched larvae are pale yellow but darken to shades of brown with longitudinal white stripes and a light-brown head capsule. Insect excrement (dark powdery material) and tangled mats of webbing on the flower heads (front or back) indicate larval activity (see fig. 9). Mature larvae drop to the ground on a strand of silk, crawl into cracks in the soil, spin cocoons, pupate, and later emerge as adults. There can be 3 generations of head moth per year.

In California, the sunflower moth likely overwinters as a larva in the cocoon stage in the soil. In colder climates, such as Midwestern states, the moth is migratory. In the Sacramento Valley, the moths begin to emerge in June and are generally most troublesome in July and August. Early-planted fields sometimes escape moth damage, as moths seem to build up on early planted fields and disperse into later planted fields when they reach greater numbers. In the Imperial Valley, plantings are generally early enough that they escape head moth flights, but if one occurs, it would be in May.

Significant outbreaks of sunflower moth can occur, with yield losses of 30 to 60 percent and occasionally 100 percent in fields where the moths are not controlled. The only way to effectively and

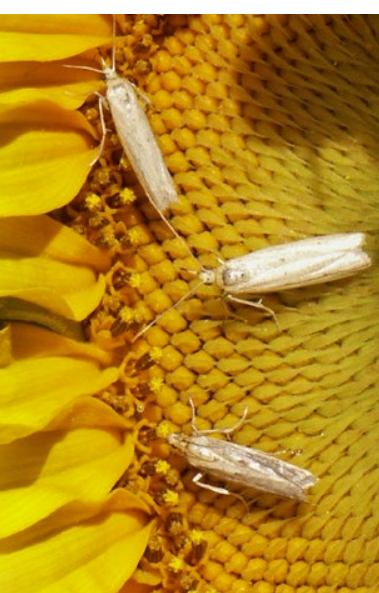

Figure 8. Sunflower head moth adults, Homoeosoma electellum. Photo: J. P. Michaud.

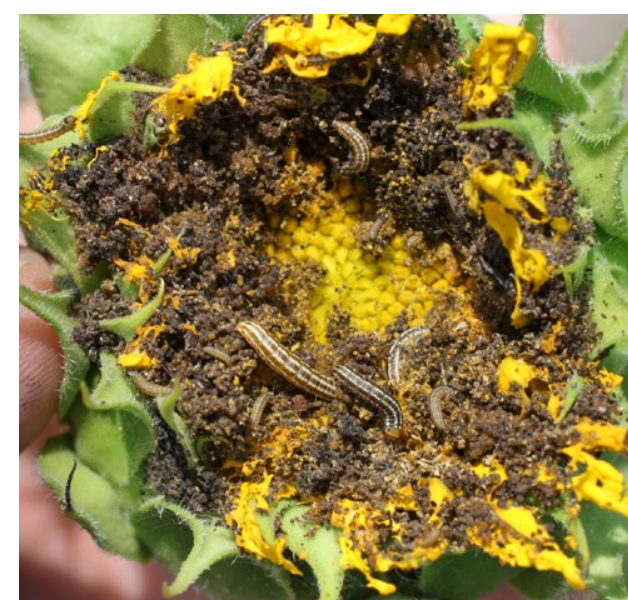

Figure 9. Sunflower head moth larvae, $H$. electellum. Photo: J. P. Michaud. 
economically manage this pest is through insecticide treatments. There are no effective cultural practices, and biocontrol cannot be relied on because the primary brachonid parasitoid wasp in sunflowers (Dolichogenidea homoseomae) cannot readily reach the head moth larvae deep in the florets with its ovipositor or break through the seed shell to reach the larvae and sting them.

Sunflower moths can be monitored using Pherocon IIB pheromone traps baited with sunflower moth pheromone lures. Two traps are generally placed along the north and south side edges of fields, taking advantage of the prevailing winds to maximize trap catches. Traps should be monitored weekly, and more often during bloom when sunflowers are most sensitive to damage by the moths. When trap thresholds reach 4 or more moths per night, especially with July and later-blooming fields, the field should be treated with an insecticide to prevent damage and crop losses, especially from secondary pathogens.

When using insecticides during bloom, it is critically important to protect honey bees to promote bee activity and crop pollination. If an insecticide treatment is needed, spray before hives are brought into fields prior to bloom or early in the morning before bees are visiting flowers. Insecticides that control head moth include Coragen (chlorantraniliprole), Warrior or Asana (pyrethroids), and XenTari (Bacillus thuringiensis). Coragen does not control adult moths but gives good caterpillar control with recommendations to apply twice, once at the late flower bud stage (R3) and again at the very beginning of bloom (R5.1), to ensure good coverage and protection. Coragen is relatively safe for bees, but applications should be made early in the morning when bees are less active to protect them from harmful effects of sprays.

\section{Lygus Bug}

Lygus bugs (Lygus spp.) are small plant bugs with a very distinctive yellow V on their back (fig. 10). They are serious pests of numerous crops, including strawberries, beans, and cotton. In confectionarytype sunflowers, feeding damage causes brown spots known as kernel brown spot (fig. 11), reducing the quality of the seed for the snack food industry. However, the impact of Lygus on hybrid seed

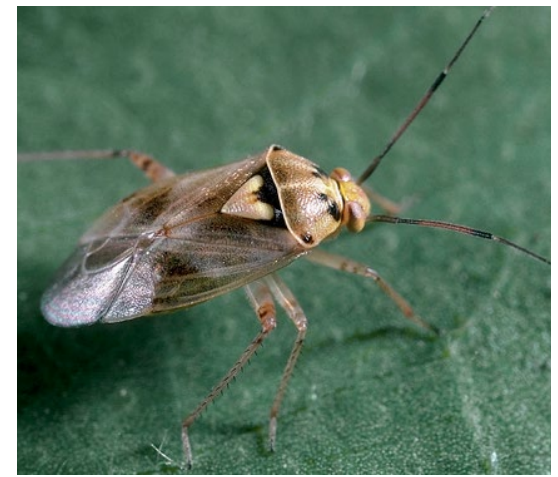

Figure 10. Lygus bug adult, Lygus spp. Photo: UC IPM.

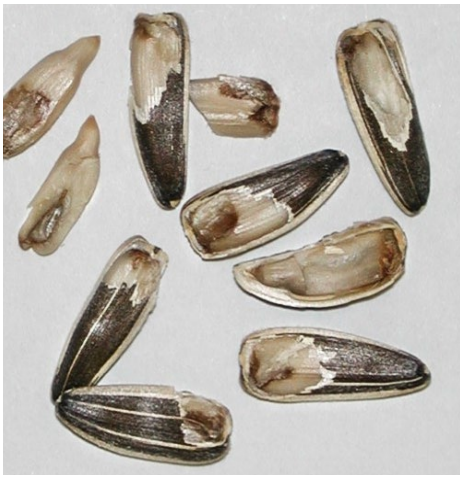

Figure 11. Kernal brown spot in confectionary sunflowers caused by Lygus bug feeding damage. Photo: L. Charlet.

production is unclear. Lygus feeding damage may reduce sunflower seed germination, a focus of current UC ANR research.

\section{Western Flower Thrips}

Western flower thrips (Frankliniella occidentalis) are tiny, slender, light-yellowish insects. The nymphs are wingless, while adults have clear, slender wings (fig. 12). When they feed, they generally cause leaves to be deformed, but they also leave behind silver patches on the lower side of leaves with tiny black fecal pellets. Plants usually outgrow the problem, just as they outgrow severe leaf tattering from wind damage. However, high numbers of thrips and heavy feeding damage can injure seedling stands if temperatures are high (above $90^{\circ} \mathrm{F}$ ) and plants are water stressed, and they may require a pesticide treatment for control to prevent stand loss.

Two-spotted Spider Mite

Two-spotted spider mites (Tetranychus urticae) are found

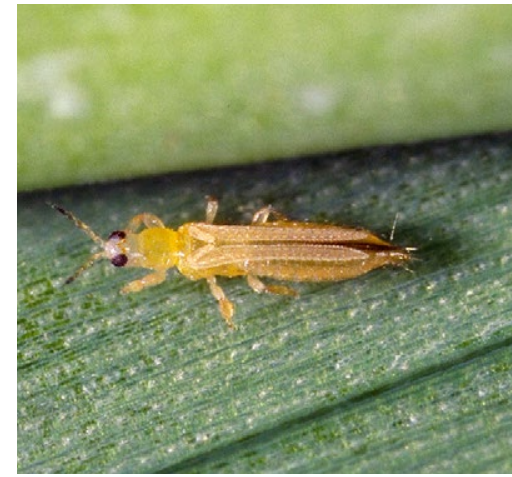

Figure 12. Western flower thrips Frankliniella occidentalis. Photo: UC IPM. 


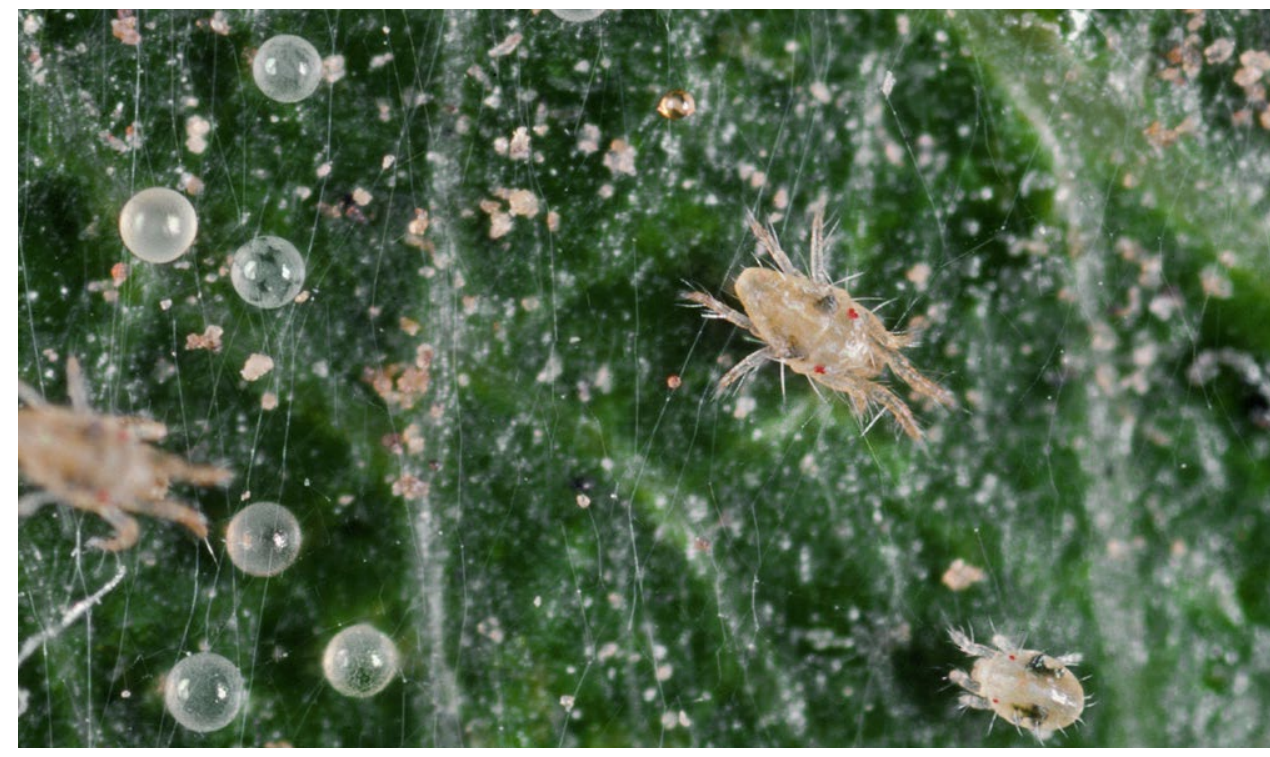

Figure 13. Two-spotted spider mites, Tetranychus urticae. Photo: UC IPM.

in sunflowers, particularly later in the season as the plants senesce. Mites are small, pinhead-sized, oblong, and yellowish with two dark pigmented spots, and they have eight legs (fig. 13). The eggs of spider mites are whitish and spherical and can be seen with a hand lens. Spider mites are usually found on the underside of leaves, with colonies beginning on the lower (older) leaves and moving upward on the plant. Spider mite feeding damage first appears as stippling (small whitish spots) on leaves. As numbers increase, spider mites spin fine webbing and move rapidly around the plant on the webbed area. Damage in heavily infested plants includes leaf desiccation with a whitish-gray cast and stunted plants. Infestations are usually associated with mature plants, dust along field edges from dirt roads, water stress, and natural senescence and control is generally not needed.

\section{Postharvest Storage Pests}

Sunflower seeds destined for export must be examined to ensure that they are free of stored product insect pests. These include dermestid beetles (Trogoderma spp.); weevils (Bruchidius spp., Sitophilus granarius, S. zeamais, Smicronyx sordidus, and S. fulvus); lesser grain borer (Rhyzopertha dominica); sawtoothed grain beetle (Oryzaephilus spp.); red and confused flour beetles (Tribolium spp.); and slender and broadhorned flour beetles (Gnatocerus spp.). More information on stored product pests and their control can be found in the pantry pests notes (UC IPM 2013) and in Residential, Industrial, and Institutional Pest Control by O'Connor-Marer (2006).

\section{Diseases}

California's dry climate, and rich, irrigated soils provide excellent conditions for growing strong, healthy sunflowers that experience fewer diseases with less severity than sunflowers grown in the main oil-production areas of the Midwest under summer rainfall. Very few of these diseases lead to yield losses in California growing conditions, but many are of quarantine significance and thus would preclude seed from being exported to foreign countries. This could cause serious economic impacts, so it is important to monitor for diseases.

The fungal diseases in California sunflower production classified as quarantine status by many foreign countries include downy mildew (Plasmopara halstedii), rust (Puccinia helianthi), and Sclerotinia (white mold) head and stalk rot (S. sclerotiorum). Fortunately, these diseases are very rare in California due to our hot, dry summers. In a 15-year study by Gulya et al. (2012), only three quarantine-type diseases were found in sunflower in California, including rust in $4 \%$ of fields, Sclerotinia rot in $2.6 \%$ of fields, and downy mildew in $0.4 \%$ of fields. Each importing country has different pathogens that are excluded. Since U. S. companies may not know in advance where the seed will be exported, it is imperative to ensure fields are free from as many diseases as possible.

If the pathogen involved is soilborne, rotate to a nonsusceptible crop to reduce the disease inoculum in the field. Downy mildew and rust are sunflower-specific diseases, so any crop is suitable to rotate for controlling them. However, for pathogens with a broad host range like Sclerotinia spp., nonhost monocots (small grains or corn) must be rotated to help reduce the sclerotia (fungal mycelium) soil inoculum. For diseases such as Rhizopus head rot, rotation offers no 
help since the fungus is ubiquitous and persists as a saprophyte on any organic matter.

Seed companies frequently treat seeds with an insecticide and several fungicides to control seedling pests and diseases to ensure good stand establishment. A mixture of seed treatments includes the insecticide Cruiser 5FS (thiamethoxam) and the fungicides Dynasty (azoxystrobin), Bion (acibenzolar-S-methyl), or Plenaris (oxathiapiprolin) for downy mildew, Maxim (fludioxonil) for Fusarium, and Apron XL (mefonoxam) for Rhizoctonia, Pythium and Phytophthora.

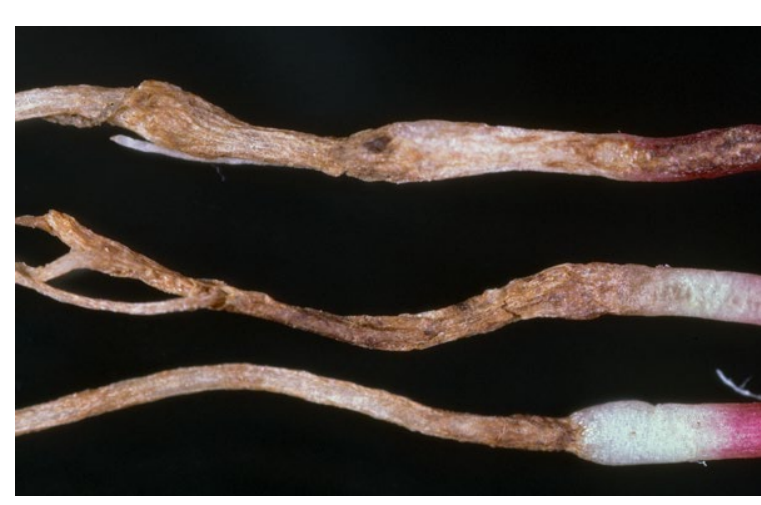

Figure 14. Pythium root rot (Pythium spp.) causes seed decay and seedling rot during germination. Photo: UC IPM.

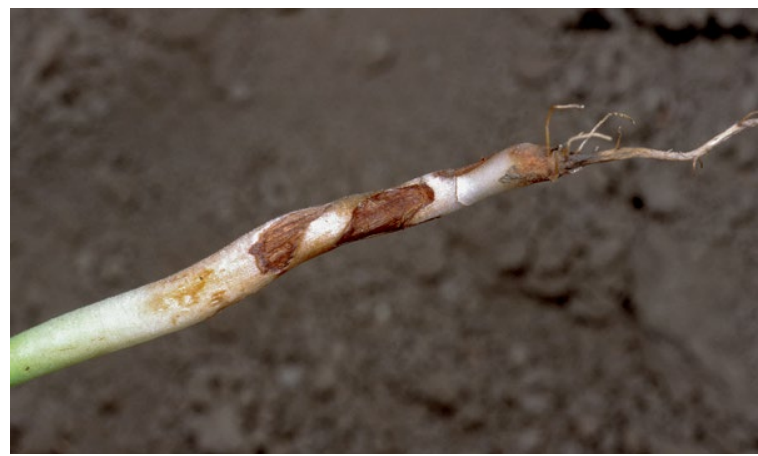

Figure 15. Rhizoctonia, R. solani, causes postemergence damping-off of seedlings. Photo: UC IPM.
Seedling Diseases

Pythium root rot (Pythium

spp.) is a damping-off disease

that thrives in cooler, wet

soils and causes seed decay

and seedling rot during

germination (fig. 14).

Rhizoctonia (R. solani), causes postemergence damping-off of seedlings that is characterized by reddish-brown lesions on stems at the soil line (fig. 15). There are no resistant hybrids or parental lines for managing Pythium- or Rhizoctoniainduced seedling diseases. Seedling diseases are controlled with seed treatments (see above).

Rust

Rust, caused by the fungus Puccinia helianthi, is characterized by cinnamonand orange-colored spots (pustules) mainly on the leaves (fig. 16). In some cases, narrow, linear pustules will be found on stems, and in severe infestations, pustules even occur on the bracts of sunflower heads (fig. 17). Many other Puccinia species have been recorded on wild Helianthus spp., but $P$. helianthi is the only one known to occur on cultivated sunflower. Most oilseed hybrids in previous years had good resistance to the prevailing rust races. However, the constan changes in the rust population in the last decade have resulted in greater rust severity and occasionally substantial losses in seed yield or seed quality, particularly in the Midwest, where rainfall and warm temperatures favor the disease.

Figure 16. Rust, a fungus, Puccinia helianthi, causes cinnamon- and orange-colored spots or pustules on a leaf. Photo: T. Gulya.

Figure 17. Severe outbreak of rust, P. helianthi, on a sunflower head. Photo: T. Gulya.
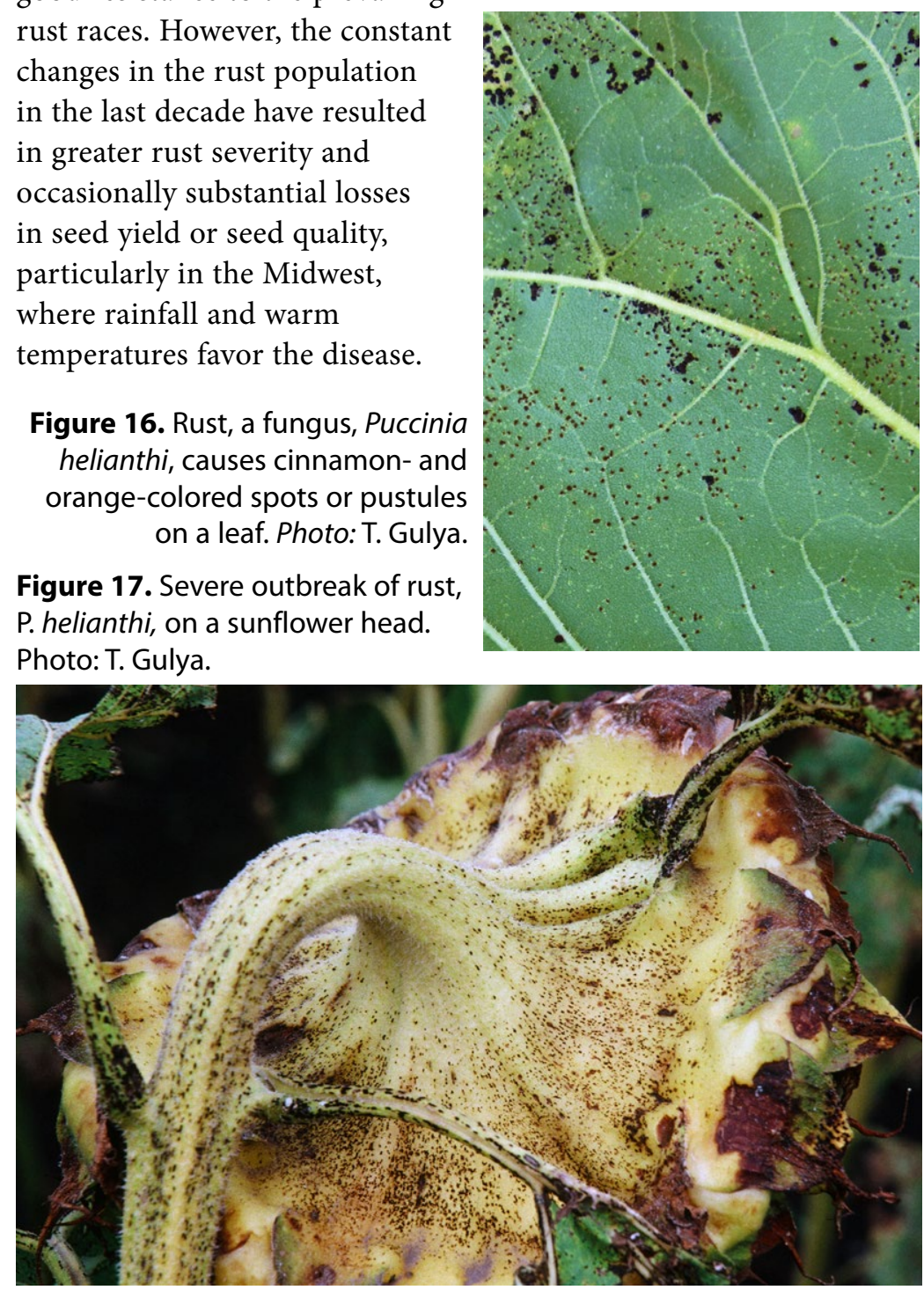
The pustules turn black with the onset of cool temperatures and develop into overwintering spores.

Rust completes its entire life cycle (five spore stages) on sunflower and does not require an alternate host like cereal rusts. Rust overwinters on plant debris and infects volunteer seedlings or wild sunflowers, and spores are spread by wind to other sunflower plants. Rust multiplies rapidly under favorable conditions of warm temperatures and either rain or dew. Thus, even in dry years, if night temperatures are low enough to promote dew formation on leaves, this minimal amount of leaf wetness will be sufficient to initiate rust infection. Excessive rates of nitrogen fertilization may result in excessive foliage, which increases humidity within the canopy and favors rust development.

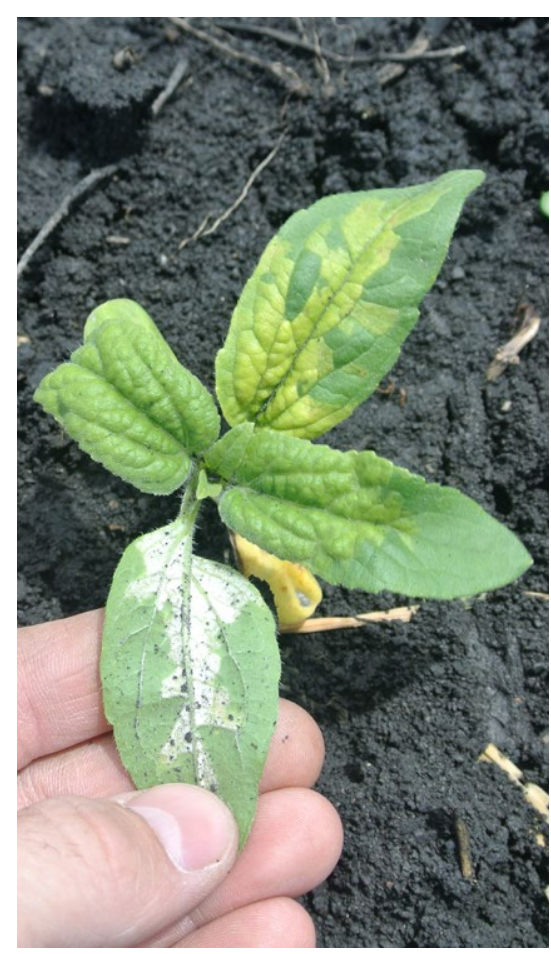

Figure 18. Downy mildew, a fungus, Plasmopara halstedii, infecting a lower leaf suface. Photo: T Gulya.

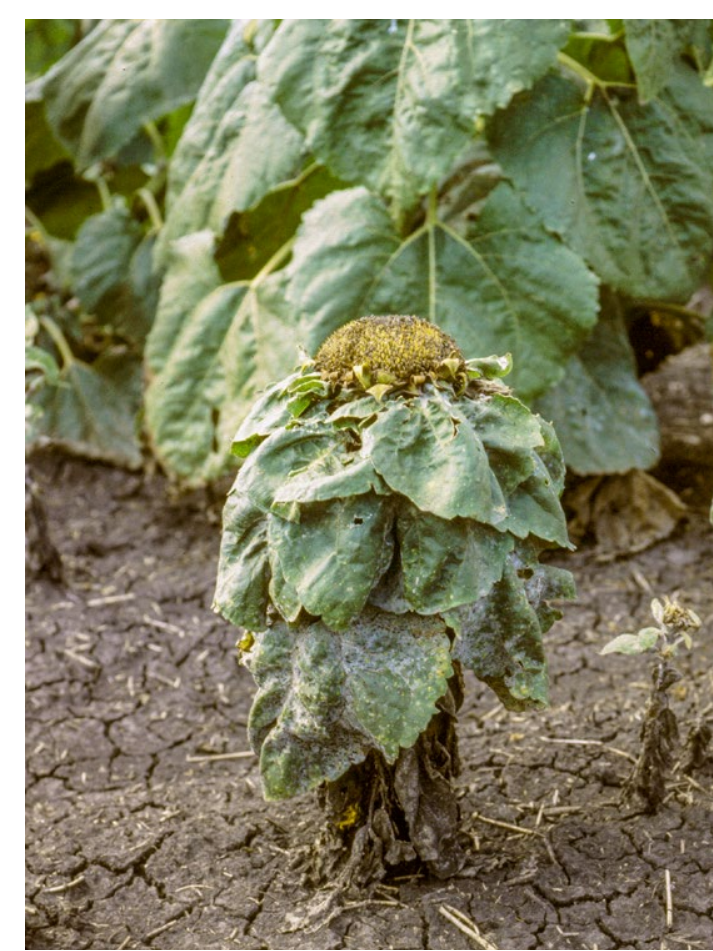

Figure 19. Severe downy mildew, P. halstedii, infection causing dwarfed plants and horizontal flowers. Photo: T. Gulya.
Destroy volunteer plants and wild annual sunflower growing near commercial fields as early in the spring as possible to reduce sources of inoculum. In seed production fields, rust resistance is generally carried by the male pollen-producing line. Since the male plants are destroyed after pollination, the concern is for the seed-bearing female plants. Several fungicides effective against $P$. helianthi with different modes of action include azoxystrobin (Quadris), Orius 3.6F (tebuconazole) and Luna (tebuconazole plus fluopyram). From a practical perspective, if any rust is found in a field, it will fail phytosanitary inspection; thus, fungicide applications that do not achieve $100 \%$ control would be unwarranted, leaving early-season roguing the most practical alternative for rust control. In oilseed-producing regions, the most effective way to avoid loss from rust is by planting rust-resistant hybrids. Seed companies are continually testing their hybrids in different locations to determine rust resistance against the various races in different regions.

\section{Downy Mildew}

Downy mildew, caused by the pathogen Plasmopara halstedii, produces white cottony masses (spores) primarily on the lower leaf surface during periods of high humidity or dew (fig. 18). Unlike downy mildew in other crops, the fungus initiates a systemic infection via root colonization of young seedlings and is systemic within the plant. Symptoms in seedlings include dwarfing and yellowing (chlorosis) of the leaves that can cause plant death. If plants are not killed in the seedling stage, heads on the dwarfed plants are borne horizontally, and the achenes are often nonviable or blanks (fig. 19). Sunflower plants are susceptible to infection in the seedling stage, before the roots are 2 inches long. This period may range up to a maximum of 2 to 3 weeks, depending on soil temperature and moisture. Cool, water-saturated soil during this period greatly favors infection. In addition to systemic infection, airborne spores may cause local lesions on leaves, which seldom lead to systemic infection.

Downy mildew is spread by soil, wind, and seeds. The fungus can persist as spores in the soil for 5 to 10 years. This pathogen does not infect any species other than those in the sunflower family, 
including all wild Helianthus species and Jerusalem artichoke (H. tuberosus). Control volunteer sunflower or wild annual sunflowers that may serve as reservoirs for the fungus. Systemic downy mildew infections cannot be controlled or eradicated by foliar fungicide sprays. The best protection against downy mildew is by planting genetically resistant hybrids or parental lines, coupled with fungicide seed treatments. In seed production fields, downy mildew resistance will generally be only on one parent line, but an effective seed treatment will be on all planting seeds. While genetic

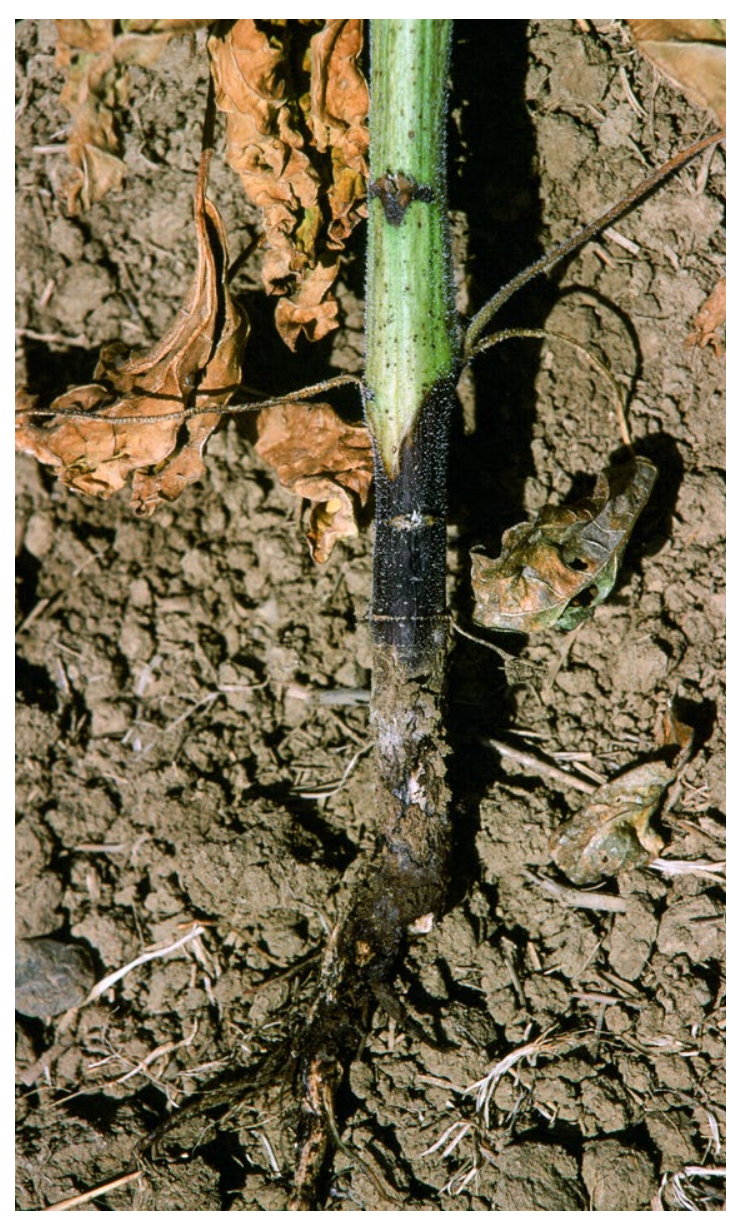

Figure 20. Collar rot, caused by the fungus Phytophthora spp. Photo: T. Gulya. resistance is effective, the downy mildew population in sunflower is ever-changing, and there are currently more than three dozen races found in the United States.

Collar Rot

Collar rot, caused by

Phytophthora spp., is a sunflower disease observed in California and not in the Midwest. This disease is favored by warm, moist soil, and is thus observed in overirrigated sections of fields in midsummer. Symptoms of the disease include a black, girdling lesion at the soil line, most often seen at the ends of rows nearest the irrigation ditch for furrow irrigated crops (fig. 20). No hybrids or parental lines are known to have resistance, and no fungicides are registered for control of this disease. The best management practice is to avoid soil compaction which could stress plants and carefully irrigate fields without excess water.

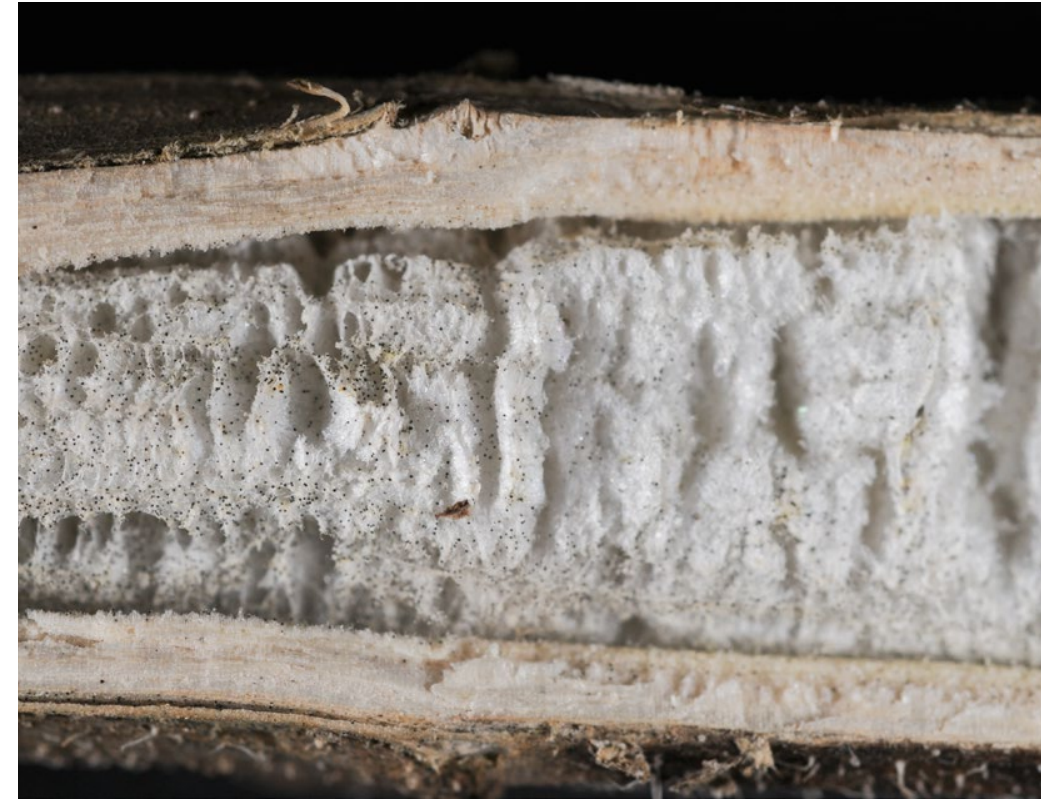

Figure 21. Charcoal rot, a fungus, Macrophomina phaseolina, with microsclerotia in the stalk resembling pepper grains. Photo: S. Markell.

\section{Charcoal Rot}

Charcoal rot, caused by the fungus Macrophomina phaseolina, generally appears after flowering but seedling blights have been reported. Symptoms on stalks appear as silver-gray lesions near the soil line, which eventually decay the stem and tap root, leaving a shredded appearance and hollow stems that lodge easily. Numerous tiny black fungal bodies (microsclerotia) resembling pepper grains will form on the inside and outside of the stalk that are barely visible, but easily seen with a hand lens (fig. 21). Another unique characteristic of charcoal rot is the compressing of pith tissue in the stems into horizontal layers, like a stack of coins. Infected plants will show undersized heads and poor seed fill.

The primary source of inoculum is microsclerotia (fungal resting bodies) in the soil, but charcoal rot can also be seedborne. Plants are infected through roots only after being predisposed by drought stress. The fungus is favored by high temperatures. Good water management to avoid stressing plants is important in managing 


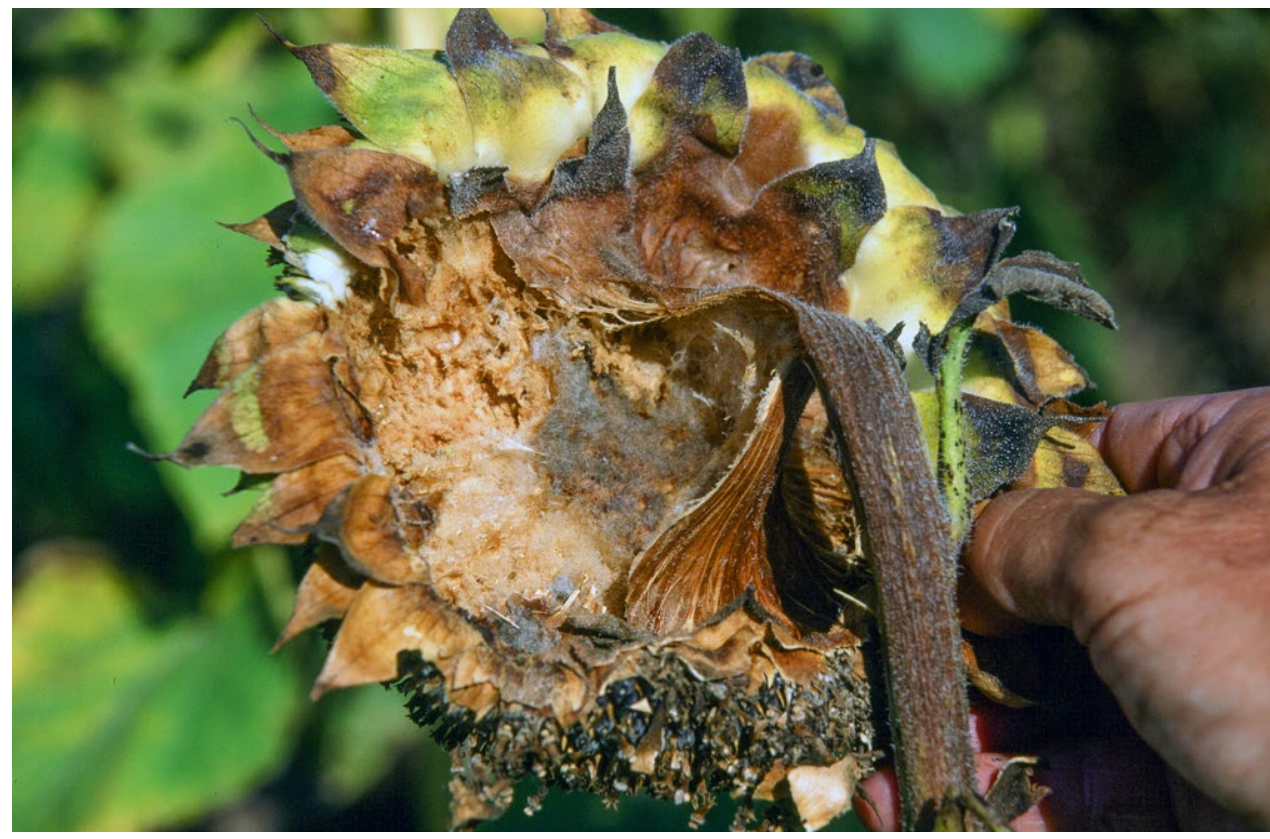

Figure 22. Head rot, caused by Rhizopus spp. fungi. Photo: T. Gulya.

this disease, particularly as the crop approaches the flowering stage. Crop rotation to nonhost crops, such as small grains, can also help reduce the disease potential. The charcoal rot fungus has a wide host range, including beans, corn, and sorghum. Charcoal rot persists in the soil for 2 to 3 years. There are no registered fungicides to control this disease.

\section{Head Rot}

Head rot, caused by Rhizopus spp. fungi, is a common occurrence on sunflowers damaged by insects (primarily head moth), birds, or hail. Rhizopus spp. rot the soft tissues of the head, turning it brown and mushy (fig. 22). Once the head is fully infected, black, pepper grain-sized spores of Rhizopus may be seen. Eventually, the head dries up and becomes hard and "mummified." The susceptibility of heads increase from the bud stage up to the full bloom and seed development stages. Disease development is most rapid in warm, humid weather. Insect control is the main management practice

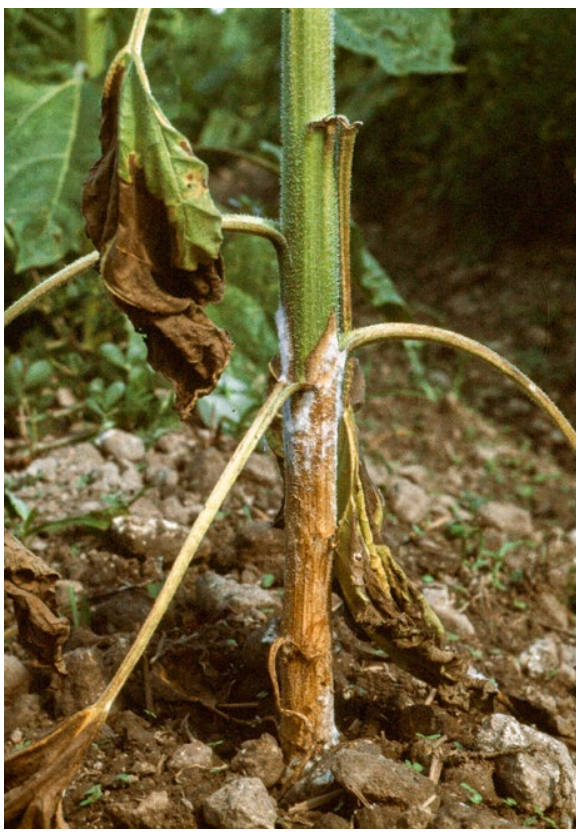

Figure 23. Basal root rot caused by white mold, Sclerotinia sclerotiorum, a fungal pathogen. Photo: T. Gulya.

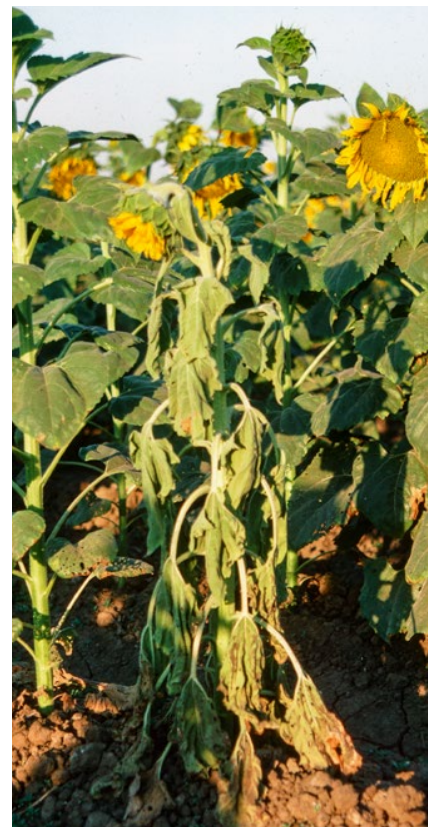

Figure 24. Wilt caused by white mold, S. sclerotiorum, infecting the plant stalk and roots. Photo: T. Gulya. to minimize Rhizopus head rot. No resistant hybrids or registered fungicides exist for Rhizopus head rot control.

\section{White Mold}

White mold, caused by Sclerotinia sclerotiorum, is likely the most serious sunflower fungal pathogen in California, the Midwest, and around the world. It is unique in that it may cause three different symptoms. It primarily causes a basal root rot (fig. 23) and ensuing wilt (fig. 24), which is caused when the soilborne sclerotia (compacted masses of fungi) germinate and infect root systems. Symptoms, which generally appear close to bloom, start as wilted leaves that never recover, and a brown, girdling lesion at the soil line. With continuous moisture, this lesion may be covered with a white fungal mass (mycelium), leading to the common name of white mold. If the stalk is split open it may be hollow in the lower 
part of the stem and will also be filled with tiny, black, irregularly shaped spores, ranging in length from a $1 / 4$ to over 1 inch.

The other two disease phases caused by white mold are midstalk rot and head rot, both of which are initiated by airborne fungal spores from the soil. When the spores land on injured leaf tissue (such as from an insect or bird), the fungus colonizes the leaf (it cannot penetrate live intact plant tissue), then progresses down the stem, eventually causing a tan, girdling lesion at the leaf base. . The stalk becomes hollow at this point and may lodge. When the spores land on a head, they colonize dead pollen and penetrate the head. For both midstalk rot and head rot to be initiated, the spores require a continuous wet period of more than 8 hours. While summer rains are nonexistent in California's sunflower-growing regions, dew would be sufficient to allow spore germination. The fungus will eventually completely destroy the head, leaving only the vascular strands, giving the appearance of a broom. If the disease does not completely destroy the head, the resultant seeds will be smaller. Numerous fungal spores will form in the head, many of which are the same shape and size the sunflower seeds, resulting in dockage or complete refusal by the seed company. These sclerotia spores are also dispersed by a combine at harvest, resulting in a field contaminated with the fungus for several years.

White mold is best prevented by monitoring and controlling the disease in crop rotations to avoid the buildup of inoculum in the field. No fungicides are currently registered in California for white mold control in sunflower, but some are registered in other crops, such as Endura (boscalid) in beans or Pristine (pyraclostrobin and boscalid) in alfalfa. The fungus infects nearly every broadleaf crop, and the sclerotia can persist in the soil for up to a decade. While some hybrids have some level of resistance, none currently could be classified as fully resistant. A related fungus, S. minor, causes a similar basal stalk rot and wilt and is distinguished by its small, round black sclerotia, compared with the much larger and irregularly shaped S. sclerotiorum sclerotia. S. minor does not cause midstalk or head rot.

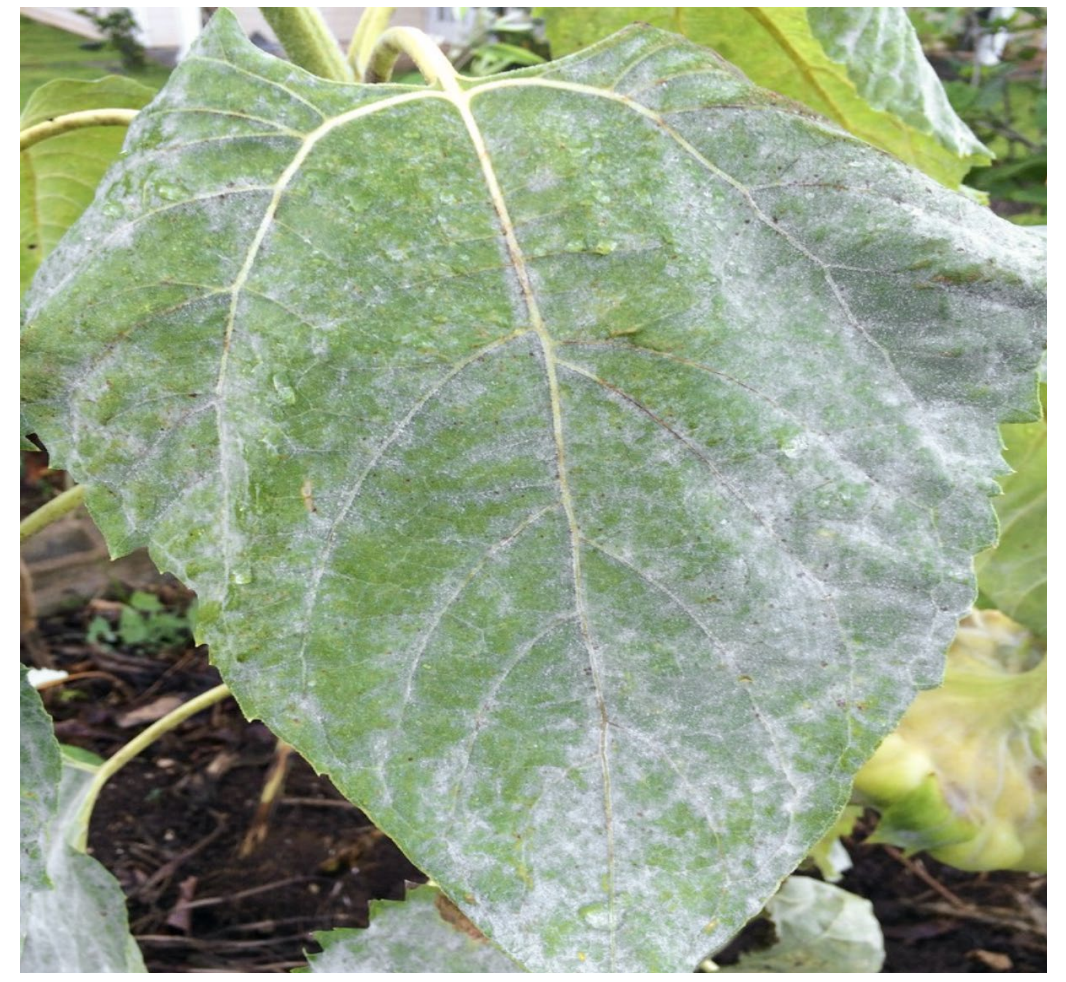

Figure 25. Powdery mildew infected leaves, caused by the fungus, Golovinomyces cichoracearum syn. Erysiphe cichoracearum. Photo: USDA.

\section{Powdery Mildew}

Powdery mildew, caused by the fungus Golovinomyces cichoracearum (syn. Erysiphe cichoracearum), produces a dull white to gray coating (fungal mycelium) mainly on the upper surface of lower leaves, causing them to dry up and senesce prematurely (fig. 25). Powdery mildew is seldom seen until late in the growing season, since senescing leaves are most susceptible to infection. Sunflower cultivars differ widely in their susceptibility to powdery mildew. The disease generally occurs late enough in the season that control measures are not needed. Powdery mildew is not currently classified as a disease of quarantine significance by any importing country. 


\section{Verticillium Wilt}

Verticillium wilt, caused by the fungus $V$. dahliae, first appears as yellowing on older leaves, causing interveinal chlorosis, with leaves turning progressively brown (fig. 26). The foliar symptoms progress up the plant until all leaves are affected. A light tan to brown discoloration develops in the vascular tissue of the stalk, especially near the base of the plant (fig. 27). Symptoms are most noticeable during later stages of plant development, with the fungus causing the pith in stalks to become blackened and shriveled (fig. 28).

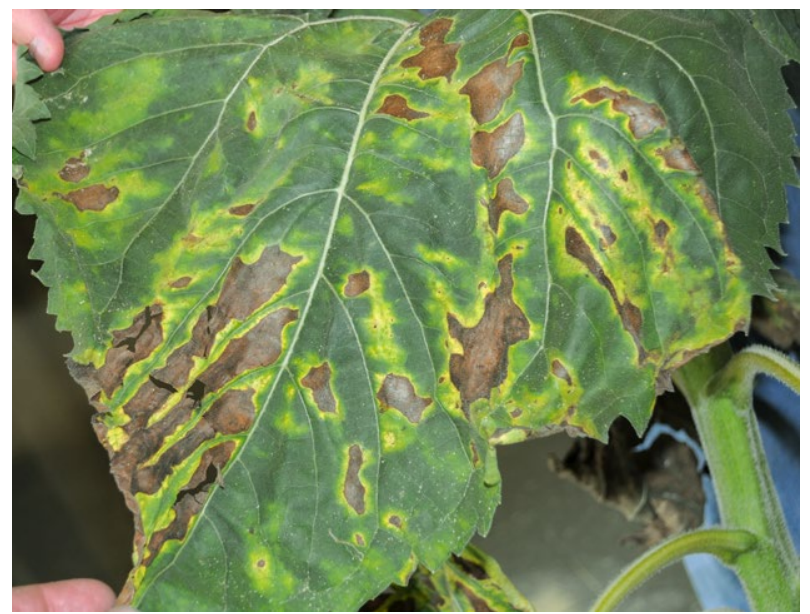

Figure 26. Verticillium wilt, symptoms, caused by the fungus V. dahliae. Photo: S. Markell.

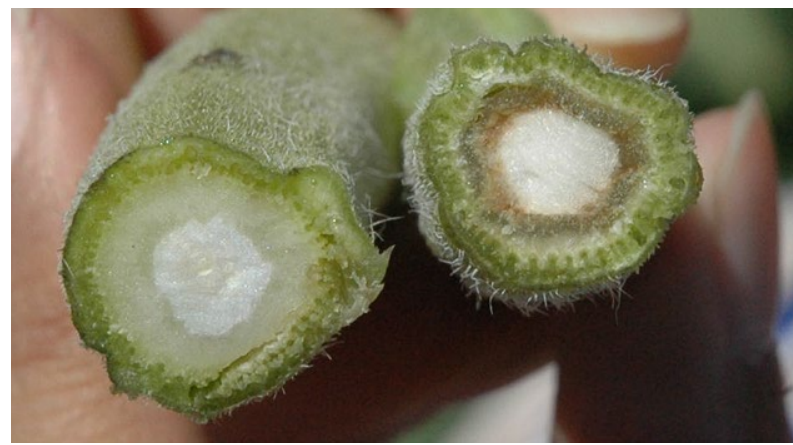

Figure 27. Verticillium wilt causing a brown discoloration in the vascular (xylem) tissue of the stalk. Photo: T. Gulya.

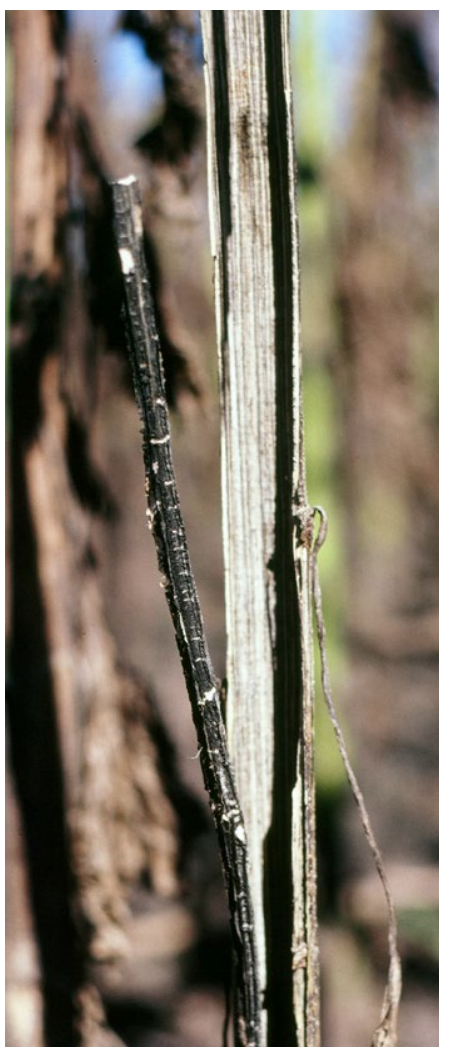

Figure 28. Advanced verticillium wilt symptoms during later stages of plant development, the pith in stalks to become blackened and shriveled Photo: T. Gulya.
Verticillium wilt reduces plant vigor and yield and can eventually kill infected plants.

The fungus survives as microsclerotia (compacted masses of fungi) in the soil. Once established in a field, it persists indefinitely and can cause disease whenever a susceptible host is planted, which includes a large number of crops as well as weeds. The disease is favored by cool soil and air temperatures. To manage Verticillium wilt, rotate to nonsusceptible crops, such as small grains and corn, and Verticillium resistant crops (such as certain varieties of tomatoes) to help reduce the soil inoculum. Field sanitation, especially washing field equipment, is important to prevent movement of infected soil to clean fields.

\section{Southern Blight}

Southern blight, caused by Sclerotium rolfsii, is a soilborne fungal pathogen that initially causes a yellowing of the foliage with a slight darkening of the stem just above the soil line. Lesions rapidly develop, girdling the stem, and causing sudden and permanent wilt of the plant (fig. 29). The fungus colonizes the root system and lower stem, eventually destroying the pith, much like the damage from white mold. White mats of fungi develop on the stem and nearby soil when there is sufficient soil moisture. In a few days, tan to brown spherical sclerotia (tiny, compact masses of hardened fungi) may appear on the fungal

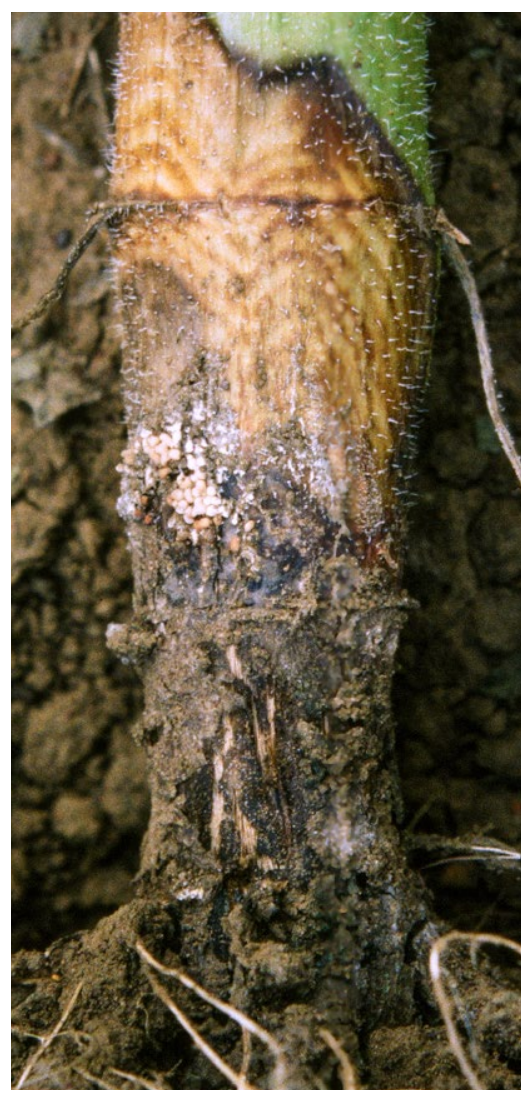

Figure 29. Southern blight, Sclerotium rolfsii, a fungal mat pathogen infecting roots and girdling a stalk at the soil line. Photo: T. Gulya. 


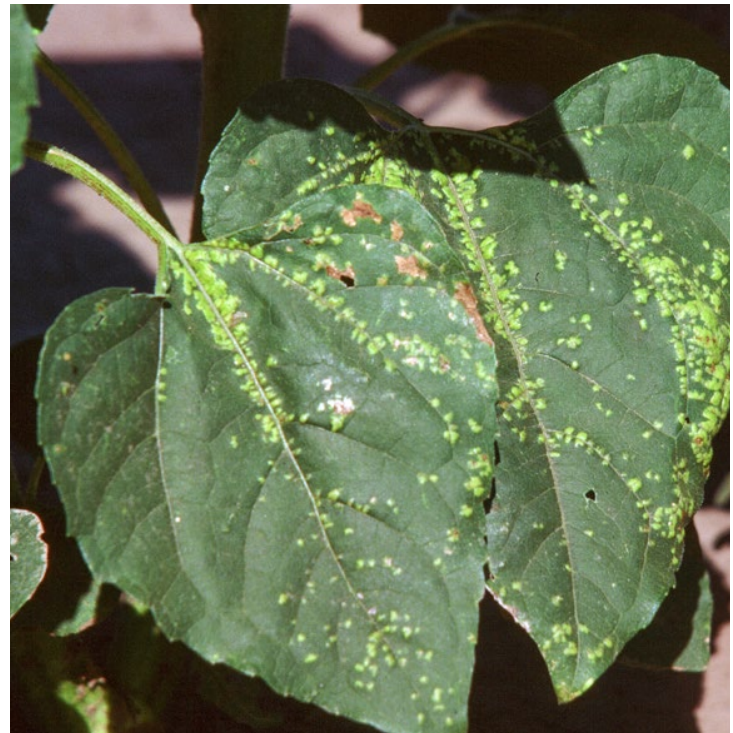

Figure 30. White rust, Albugo tragopogonis syn. Pustula obtusata, top leaf symptoms Photo: T. Gulya.

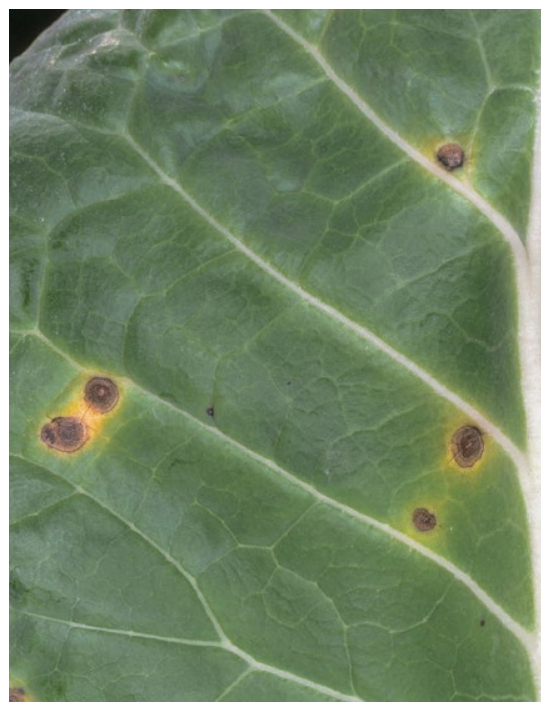

Figure 32. Alternaria leaf spot caused by Alternaria helianthi and A. zinnia fungi. Photo: UC IPM.

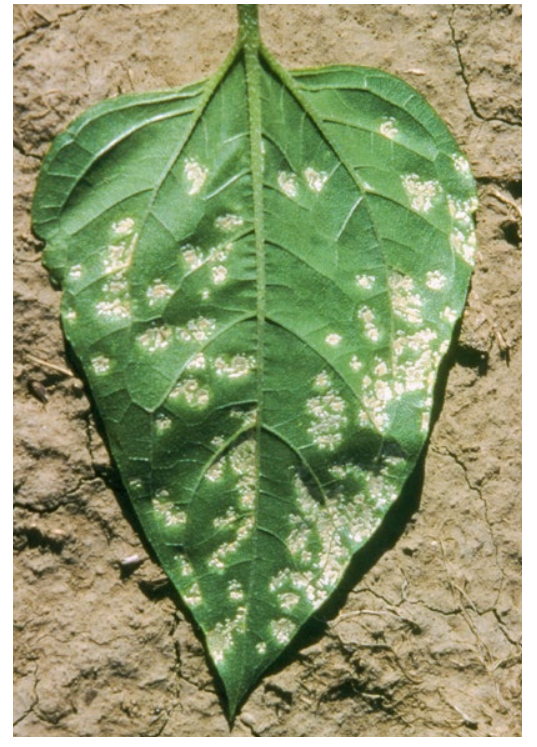

Figure 31. White rust,

A. tragopogonis, lower leaf symptoms. Photo: T. Gulya.
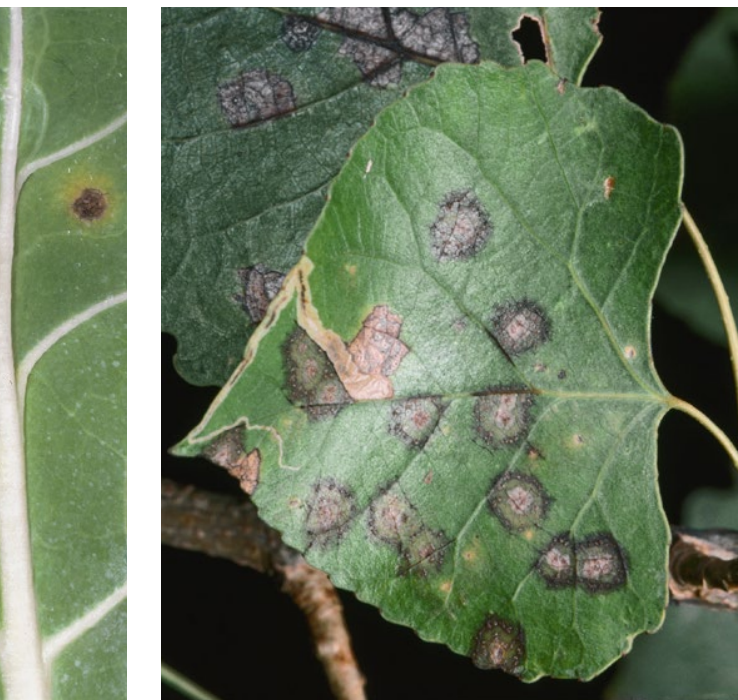

Figure 33. Septoria leaf spot fungus, Septoria helianthi. Photo: UC IPM. mat. If present, these are a good diagnostic feature of this disease. Southern blight is usually a minor disease of sunflower and other crops in California. However, temperatures above $85^{\circ} \mathrm{F}$ together with high moisture favor the disease. The fungus survives for a long time in the soil as sclerotia. Rotations are not considered effective since this pathogen has over 500 hosts. However, it is thought that rotations to corn or small grains for at least 2 years may reduce soil inoculum; studies are underway to determine whether these rotations are effective. Discing and deep burying crop stubble helps destroy sclerotia.

\section{Other Diseases}

A number of pathogens are not yet found on sunflower in California, but have import restrictions, so they should be monitored. These include the following foliar diseases:

- white rust fungus (Albugo tragopogonis syn. Pustula obtusata; top leaf symptoms, fig. 30, lower leaf, fig. 31)

- Alternaria leaf spot (Alternaria helianthi and A. zinnia fungi, fig. 32)

- Septoria leaf spot (Septoria helianthi fungus, fig. 33)

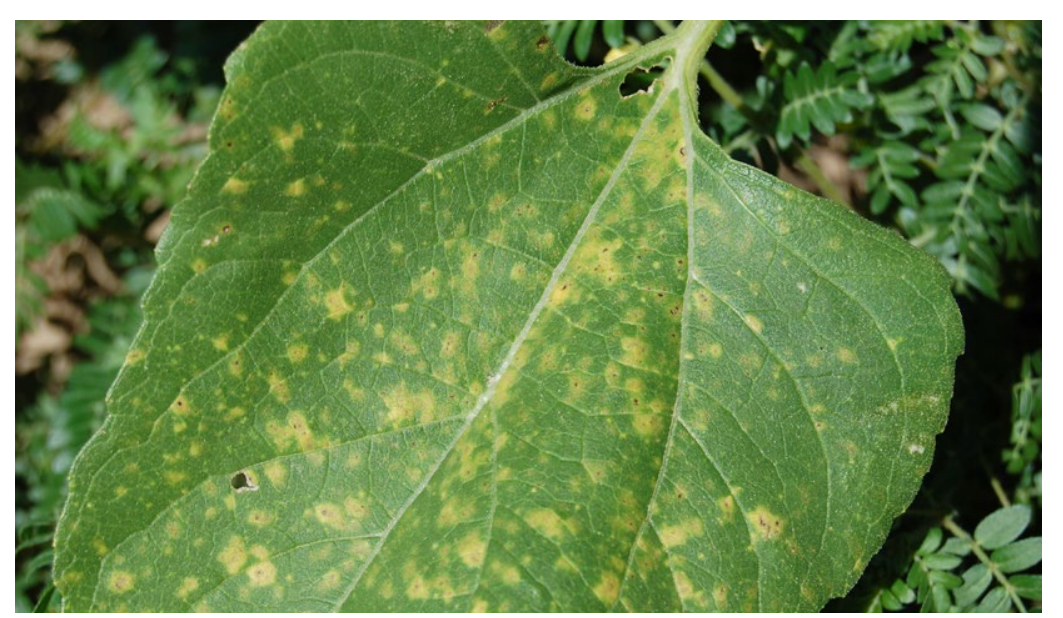

Figure 34. Bacterial leaf spot, Pseudomonas syringae pv. helianthi and P. cichorii. Photo: T. Gulya. 
- bacterial leaf spot (Pseudomonas syringae pv. helianthi and $P$. cichorii, fig. 34)

- apical chlorosis caused by a toxin produced by Pseudomonas syringae pv. tagetis, fig. 35 .

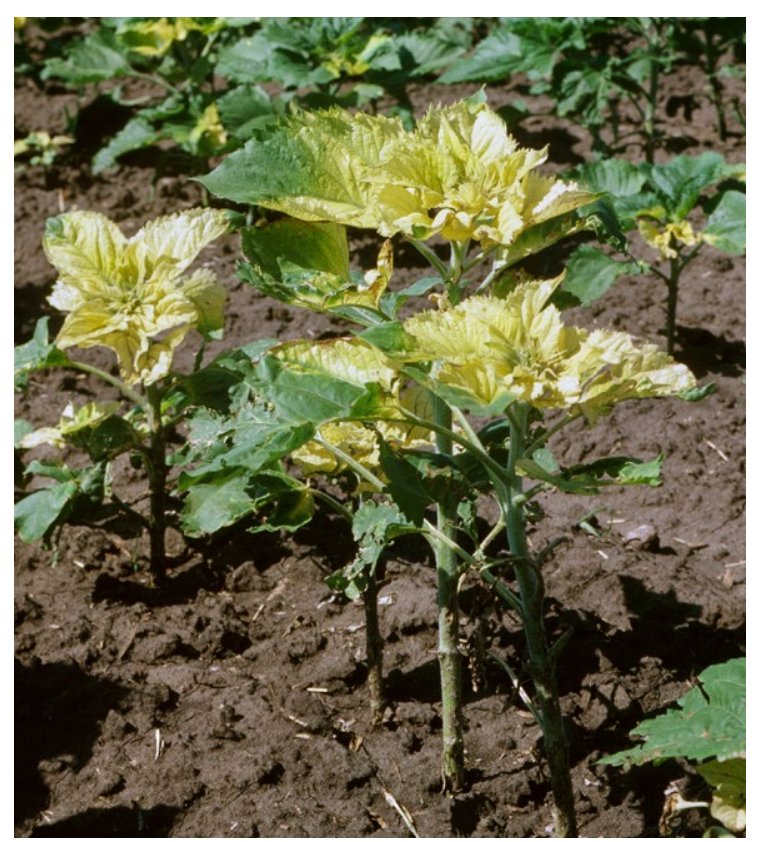

Figure 35. Apical chlorosis caused by a toxin produced by Pseudomonas syringae pv. tagetis. Photo: T. Gulya.

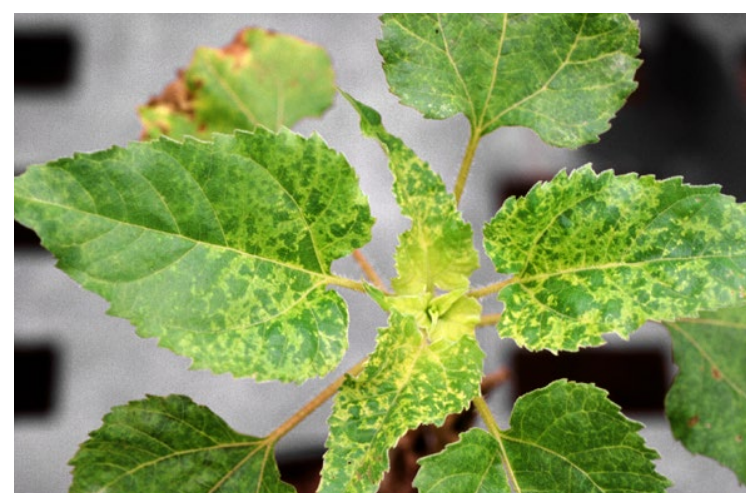

Figure 36. Sunflower mosaic virus. Photo: T. Gulya.

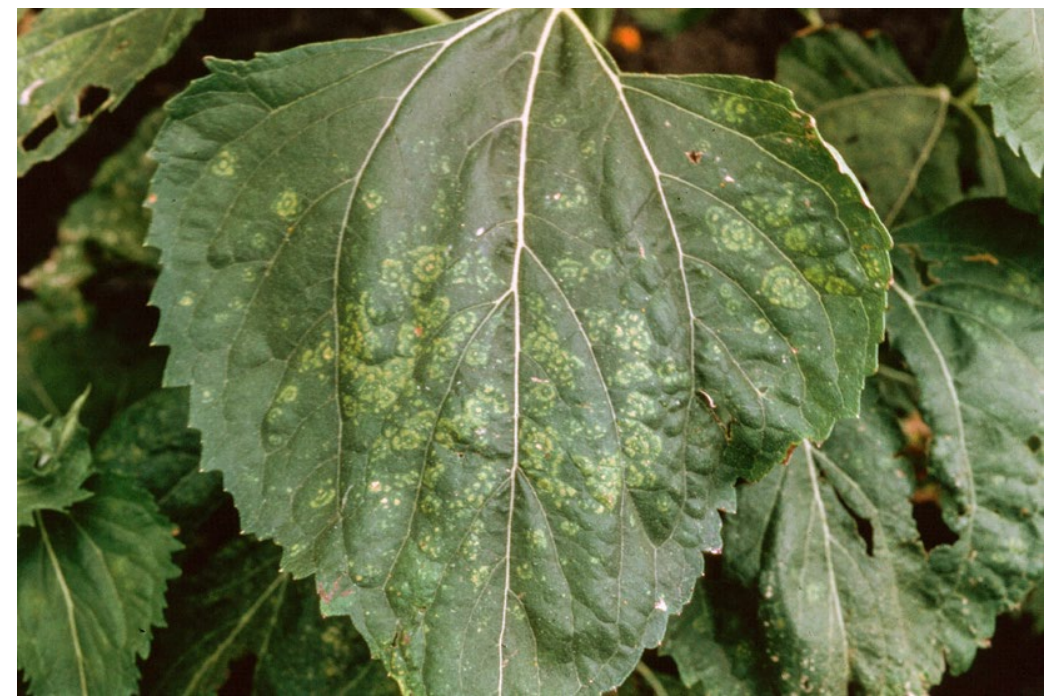

Figure 37. Sunflower ringspot virus. Photo: T. Gulya.

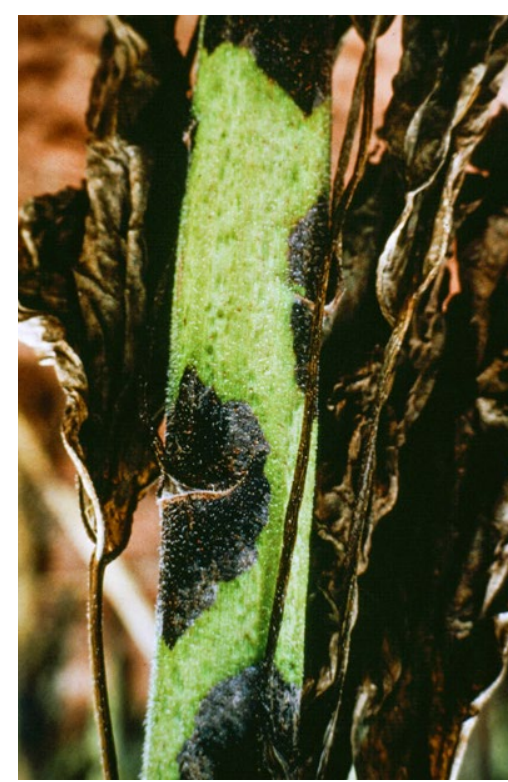

Figure 38. Phoma black stem, caused by the fungus, $P$. macdonaldii Photo: T. Gulya.

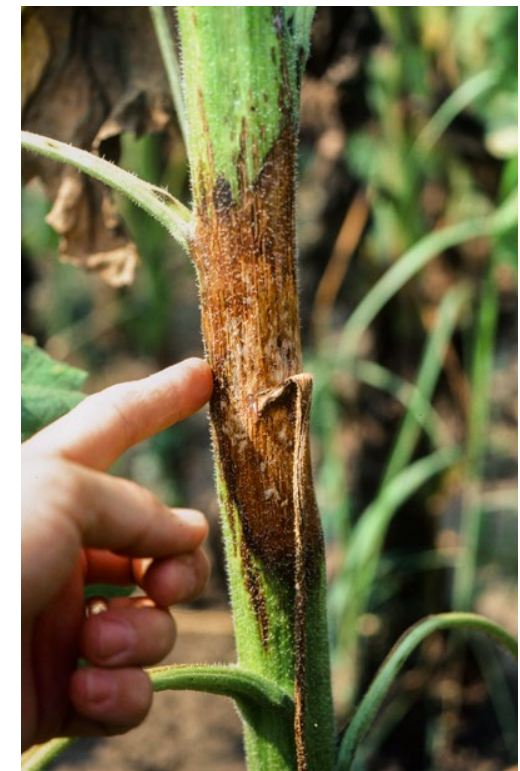

Figure 39. Phomopsis canker, caused by the fungi, Diaporthe helianthi, D. gulyae, and others. Photo: T. Gulya. 


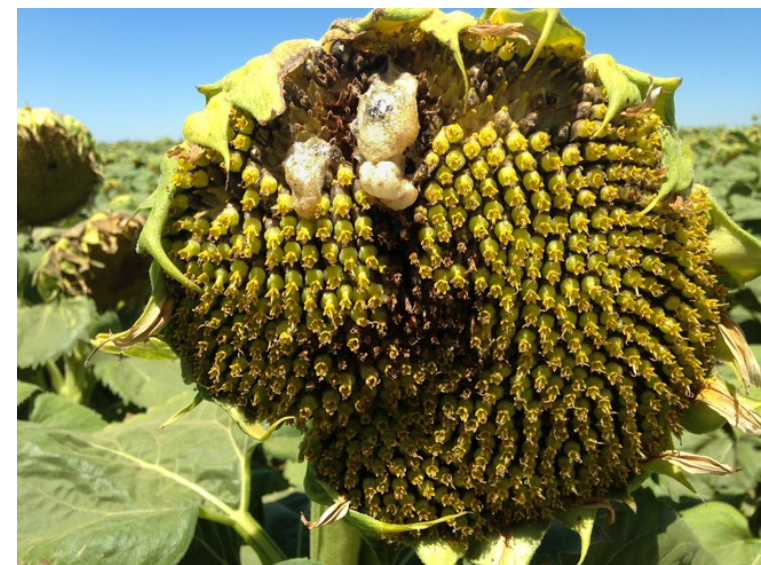

Figure 40. Foamy head rot in sunflower, an abiotic disorder. Photo: R. Long.

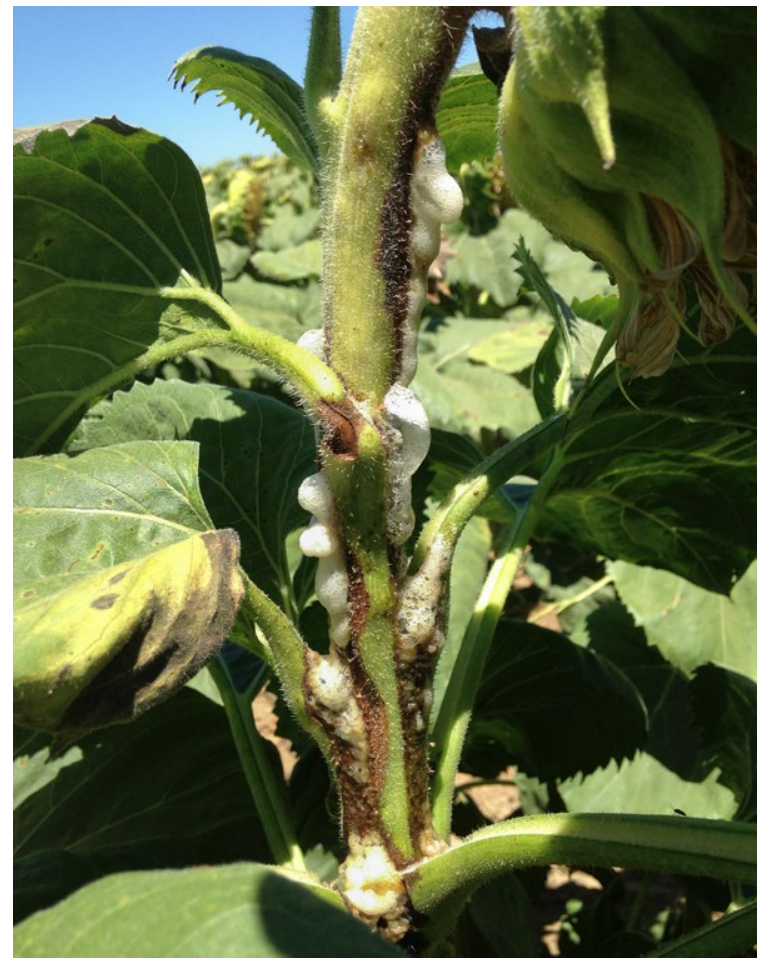

Figure 41. Advanced stages of foamy head rot infecting a sunflower stalk. Photo: R. Long. disorder given that it appears to be varietal and physiological.

Foamy head rot of sunflower produces copious white frothy material that exudes from the flower heads, leaf petioles, and stalk (figs. 40 and 41). No wounds are obvious, though insects such as stink bugs and ants are often attracted to the sweet, alcohol-smelling frothy sap. Yields and seed quality are reduced, depending on the severity of the problem. This disorder has been observed only in female lines of select varieties, with certain genetics that predispose them to this problem. This condition usually occurs during hot, dry spells with ample soil moisture. Despite extensive testing, no pathogens have been identified as causal agents (Venette et al. 1994). Excessive heat may cause splitting or microwounds that allow the ingress of organisms that otherwise would not be harmful, much like Rhizopus head rot (a fungus) following insect or bird damage to flower heads. The foamy disorder was observed in the same female parent lines in 1993 and 2014, where it was fairly uniformly distributed throughout fields. Similar symptoms were found in some female plants in 2017, after a heat wave, likely in a different parent line compared with earlier years, as damage was not as widespread as occurred in previous years.

Excessive heat waves can also injure sunflowers, especially during the early reproductive stages through bloom (R1-R5). For example, in 2017 in the Sacramento Valley, the high temperatures in mid June were $100^{\circ}$ to $106^{\circ} \mathrm{F}$ for 8 consecutive days during the R1-R4 stage for some fields. Heat damage that followed included flower buds that did not develop or they partially opened (fig. 42), with some seed set, but yields were significantly reduced. Again, the heat damage was observed only in female lines and not in the males. Some parental lines showed more tolerance to the heat wave than others, with less flower damage, indicating differences in parental line susceptibility. There was some indication that heat injury to sunflowers was worse where fields had gravel streaks (and subsequently drier areas). This suggests that it is critical to be prepared with good irrigation management practices before heat

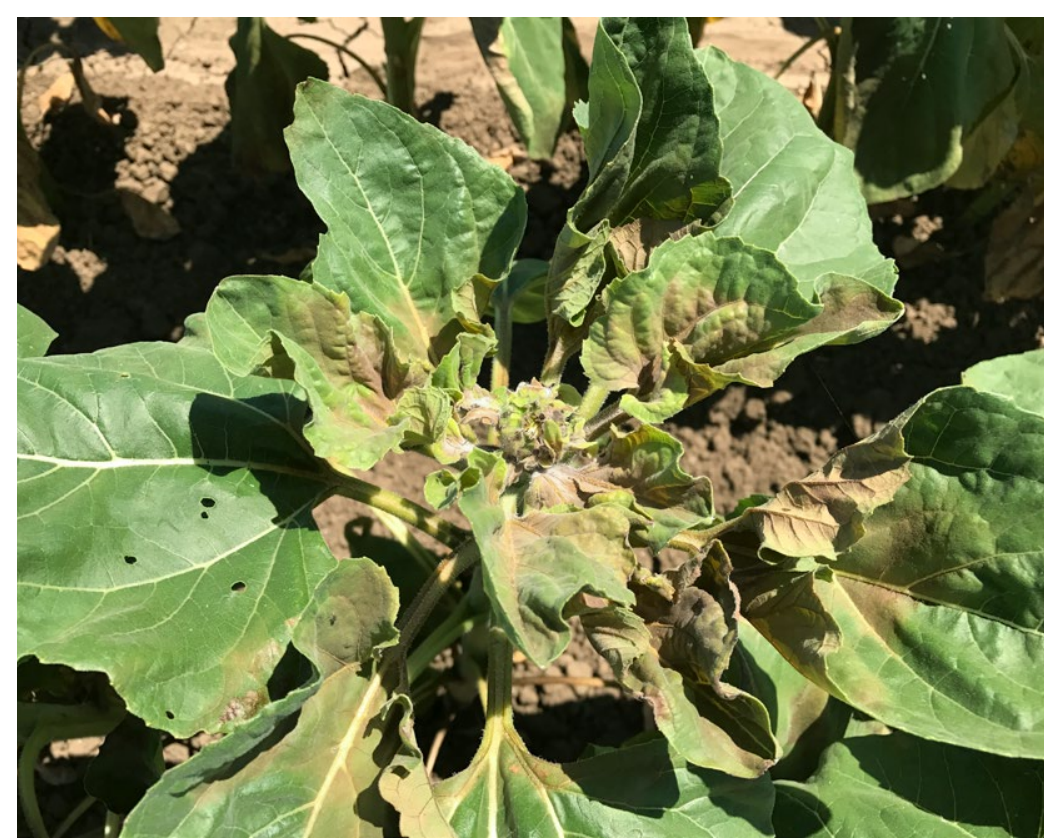

Figure 42. Sunburn damage to sunflowers can kill buds or damage them so that they do not fully open. Photo: R. Long. 


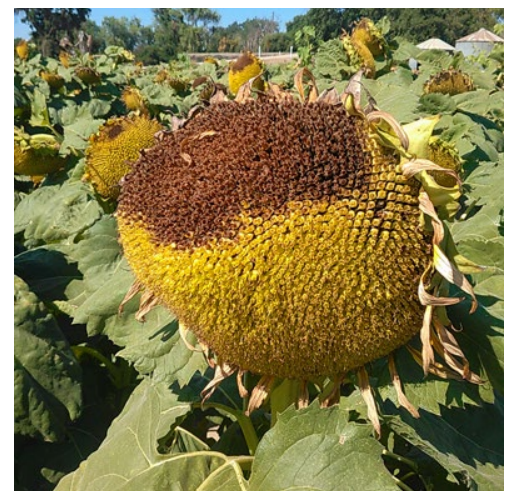

waves occur to ensure that sunflowers are not moisture stressed during extreme heat events.

Excessively high temperatures at bloom after several heat waves in 2017 also resulted in sunburn on the fully opened female flower heads (again, not males) (fig. 43), followed by a breakdown of tissue that became gelatinous from secondary pathogens.

Figure 43. Sunburn damage to sunflower heads. Photo: R. Long.

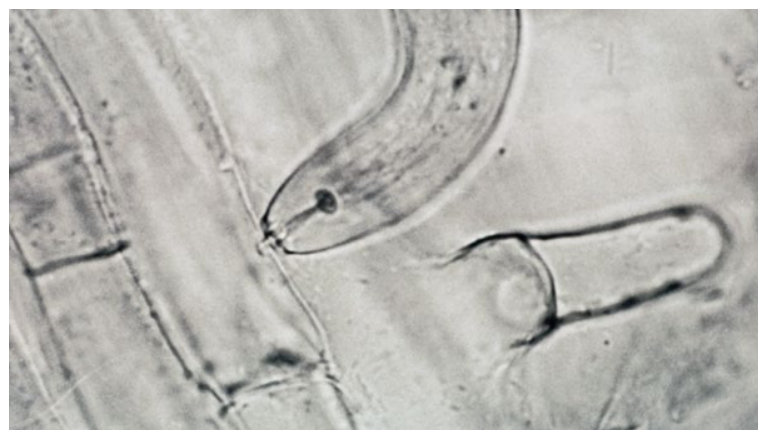

Figure 44. Root lesion nematode adult, Pratylenchus penetrans, feeding on a plant root. Photo: UC IPM.

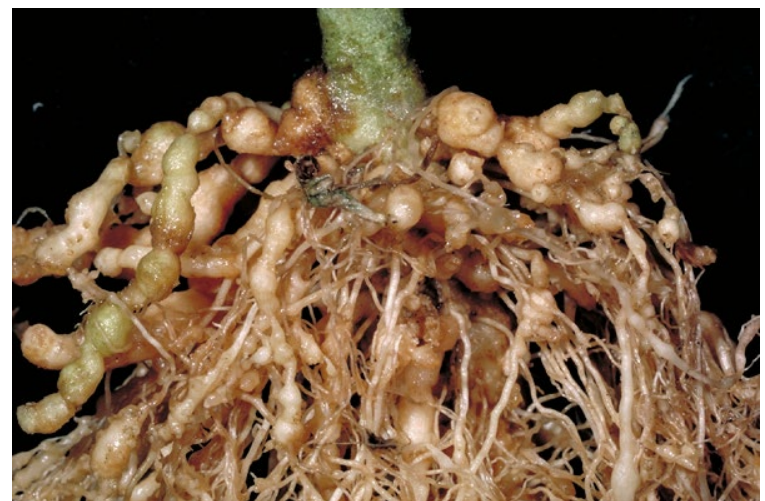

Figure 45. Severe galling of tomato roots by the root knot nematode, Meloidogyne spp.. Photo: UC IPM.

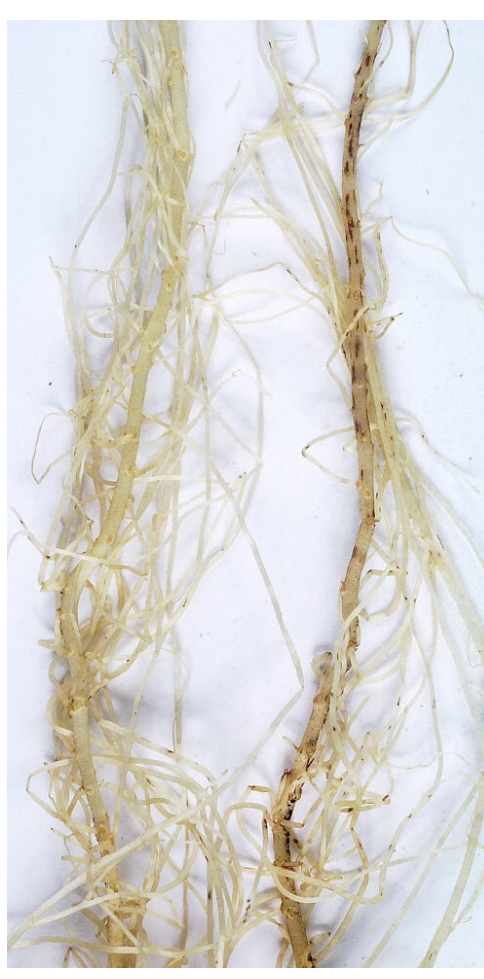

Figure 46. Brown scarring on plant roots caused by lesion nematodes, Pratylenchus spp. (top). Healthy root (left), nematode damage (right). Photo: G. S. Abawi.
Symptoms were uniform on plants throughout fields where heatrelated damage occurred, which is a clue that the cause was abiotic or environmental and not due to a disease. In other fields there were empty or undeveloped hulls (shell) due to poor pollination from a lack of honey bee activity from the heat wave (see the section "Pollination," under "Crop Production Methods," above).

\section{Nematodes}

Nematodes, microscopic, wormlike organisms that feed on plant roots, are seldom a problem in sunflower production (fig. 44). However, most nematodes found in California have a wide host range, so it is possible that nematode damage could occur. Nematodes that exist in California that might parasitize sunflower include the root knot nematode (Meloidogyne spp.), which produces galls on the roots (fig. 45), and the lesion nematode (Pratylenchus spp.), which causes brown, discolored scarring on the roots (fig. 46). If nematodes are suspected, soil samples can be taken and sent to a lab for pest identification. The only economical management tool is rotation away from any susceptible host crop (such as small grains) and using resistant plant varieties in crop rotations, such as certain varieties of tomatoes.

\section{Weeds}

Weed control is essential for maximizing sunflower seed yields and quality and for meeting seed certification standards in hybrid sunflower seed production (see the section "Crop Standards and Certification," above), especially for prohibited and restricted weeds. The most common prohibited weed in California is perennial pepperweed (Lepidium latifolium,

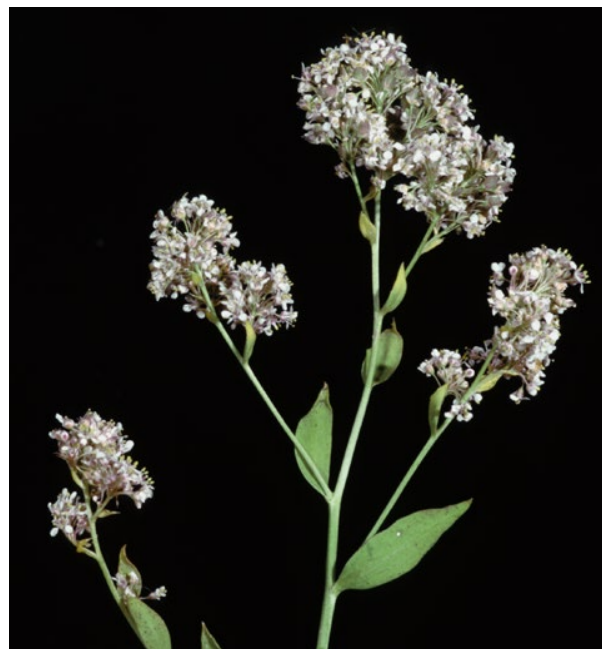

Figure 47. Perennial pepperweed, Lepidium latifolium. Photo: UC IPM. 


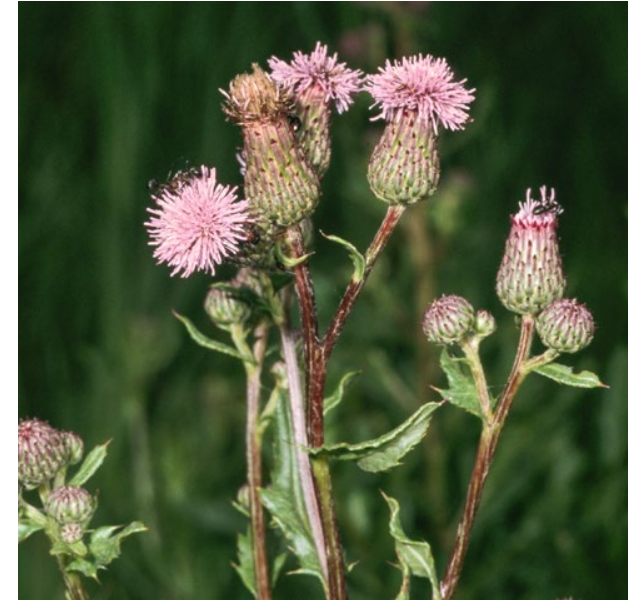

Figure 48. Canada thistle, Cirsium arvense. Photo: UC IPM.

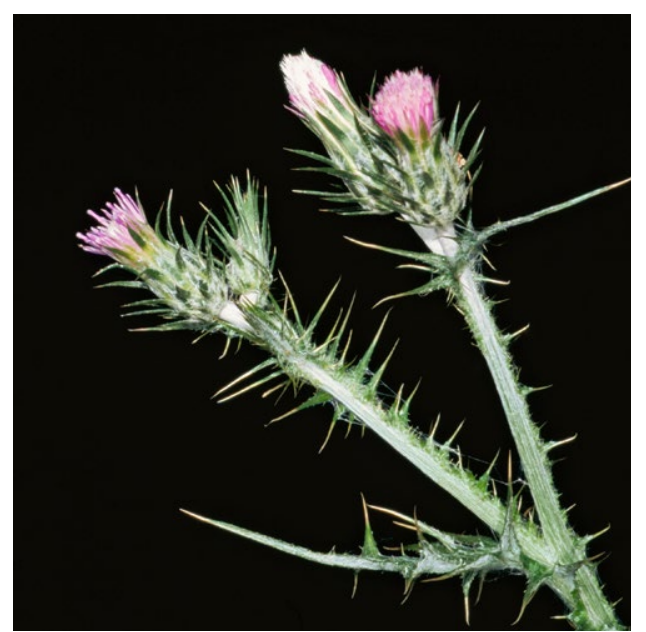

Figure 50. Italian thistle, Carduus pycnocephalus Photo: UC IPM.

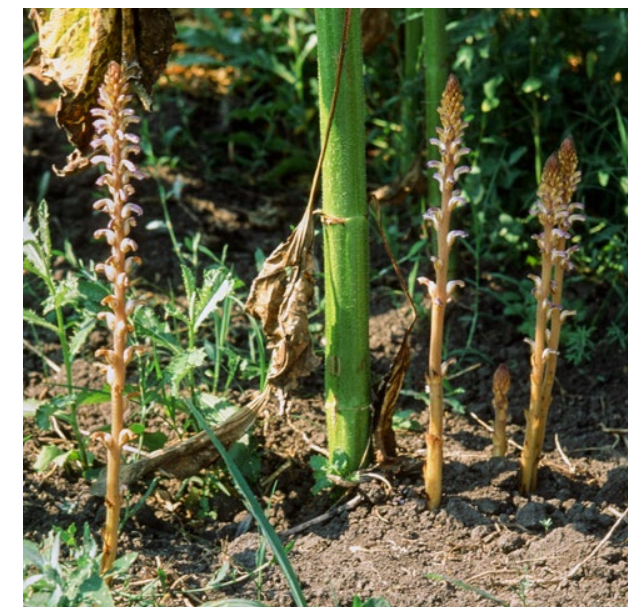

Figure 49. Branched broomrape, Orobanche ramose. Photo: T. Gulya.

fig. 47). Canada thistle (Cirsium arvense) is another prohibited weed and a problem for sunflowers grown in the Intermountain area (fig. 48). An isolated population of branched broomrape (Orobanche ramosa), also a prohibited rated species, was observed in the Sacramento Valley in 2017 and eradication efforts are in progress (fig. 49). Restricted noxious weeds are not allowed in processed (cleaned) seed lots.

Noxious weeds with a restricted rating include Italian thistle (Carduus pycnocephalus, fig. 50), slender flowered thistle (C. tenuiflorus), field bindweed (Convolvulus arvensis, fig. 51), and Johnsongrass (Sorghum halepense, fig. 52) as well as other perennial sorghum species. While the restricted noxious weed species observed in sunflower seed production are smaller seeded and can be effectively removed during seed conditioning, they should be controlled in the field to

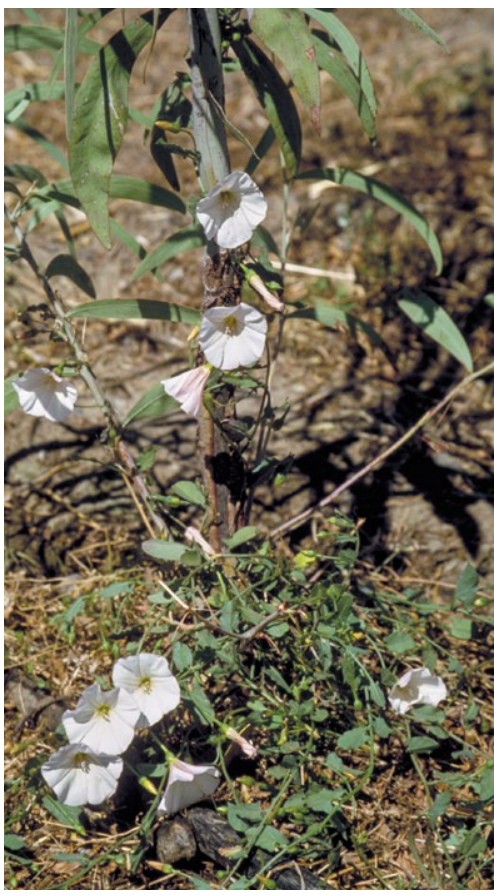

Figure 51. Field bindweed, Convolvulus arvensis Photo: UC IPM.

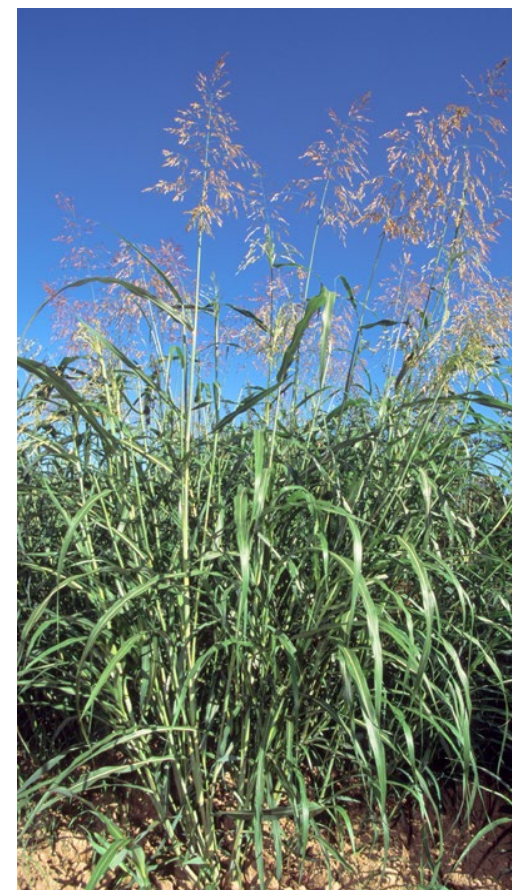

Figure 52. Johnsongrass,

Sorghum halepense Photo: UC IPM prevent risk to seed lot contamination. CCIA also requires rouging of corn and castor bean because it can be hard to remove these seeds during conditioning and there is zero tolerance for them in the seed analyses.

Weed control in sunflowers begins with knowing the field history and types of weeds in the field. Postemergence herbicide options are limited for broadleaf weed control in sunflowers once the crop has emerged, so avoid fields with weed pressure, especially for the prohibited and restricted weeds listed above. In addition, knowing the weed spectrum in the field is needed to help determine which herbicides to use at planting. Prepare a good seed bed to ensure a uniform, good stand that will help shade out and compete with weeds. Planting into moisture on subsurface drip systems, where the soil surface remains dry, helps keep weeds under control. Cultivate sunflowers at layby (along with sidedressing of nitrogen, 
if needed) to help control weeds. Seed companies may also send in roguing crews to manage weeds.

Glyphosate (Roundup) is typically used to burn down winter weeds prior to planting, then preplant herbicides are applied for spring and summer weed control. Preplant herbicides are mechanically mixed into the top 2 to 3 inches of the soil with a cultivator. The choice of herbicide depends on the weed complex present in the field. Mixtures of herbicides are often used, with rates highly dependent on the soil texture, as defined in the pesticide label. Sonalan HFP (ethalfluralin) is often used in sunflower production because it provides good control of nightshade (Solanum spp.). A tank mix of Sonalan and Medal (s-metolachlor) or Treflan (trifluralin) provides excellent control of most annual grasses, fair to good control of small-seeded broadleaves including pigweeds (Amaranthus spp.) and lambsquarters (Chenopodium spp.), and fair control of wild oat (Avena fatua), but does not control wild sunflower, cocklebur (Xanthium spp.), or wild mustard (Sinapis arvensis). Treflan has some soil residual activity and may damage oats or sorghum the following year. Prowl $\mathrm{H} 2 \mathrm{O}$ (pendimethalin) is sometimes used as preplant incorporated herbicide for weed control in sunflower production, depending on the weeds present in the field.

For postemergence weed control, Poast (sethoxydim) and Select Max (clethodim) can be used on grass weeds including cereal grains, corn, and sorghum. Surfactants (crop oil concentrates, $\mathrm{COC}$ ) and AMS (ammonium sulfate) adjuvants are recommended to enhance the efficacy of these herbicides. For broadleaf weed control, Shark (carfentrazone) can be used only as a hooded sprayer application (contact with the crop causes injury). Clearfield sunflower with imazamox tolerance and ExpressSun with tribenuron tolerance allow for the control of difficult broadleaf weeds, including cocklebur, puncturevine (Tribulus terrestris), and wild mustard. When growing varieties with these traits, be aware of plant back restrictions for subsequent crops, such as tomatoes.

Volunteer sunflowers can be a problem in subsequent crop rotations, such as wheat. A frost often kills sunflower plants out of season, but late-germinating seedlings that get buried deep during tillage and grow slowly can escape these events. Destroying the male rows soon after pollination is complete results in less viable seed remaining in the field. However, destroying them too early after pollination will result in any late-blooming females in the field having the potential to receive sunflower pollen from foraging bees exclusively from outside sources, increasing the risk of varietal contamination. In addition, avoid deep tillage (burying the seeds deeply) if possible after harvest to reduce the frequency of lateemerging sunflower volunteers. In small grains, 2,4-D or MCPA can be used for sunflower control. Watch for Clearfield and ExpressSun technology in crop rotations, as these sunflowers will not controlled by imazamox or tribenuron herbicides.

\section{Birds}

Sunflowers are vulnerable to damage by birds because the seeds are exposed and the large head serves as a perch during feeding, and birds favor them. Although many species of birds feed in maturing sunflower fields, the greatest losses are caused by migrating flocks of blackbirds (red-winged, cowbirds, and Brewer's). Although blackbirds are protected under the Migratory Bird Treaty Act, cultural practices can be used to manage blackbirds, including bird-scaring cannons that produce an extremely loud explosion (these should not be used around houses or public areas at night or numerous complaints will occur). Most growers elect to avoid planting in areas where blackbirds frequent, including the Sacramento bypass, which serves as a wildlife area. Some insectivorous birds are beneficial in sunflower fields when they prey on pests such as sunflower head moth. Also watch for bird damage on newly emerged seedlings.

\section{HARVESTING AND PROCESSING}

Only the female plant rows are harvested; males are chopped and disked after pollination and seed set. At maturity (moisture levels of 24 percent or less), females are often treated with defoliants or desiccants to dry them down more quickly in preparation for harvest. This reduces exposure to vertebrate pests, such as birds, weathering (such as sunburn damage or rain), variable maturity due to multiple soil types, and harvest issues due to live, green weeds. 
Harvest aid products used include the herbicide paraquat, a desiccant, as well as sodium chlorate-based defoliant materials (e.g., Defol 750). Sodium chlorate materials are contact only and are very effective as defoliants during hot, dry conditions. Paraquat is most effective during cool or cloudy weather when it is better absorbed into the stem and leaf material, allowing it to diffuse more readily into the plant before being activated by sunlight. Never use glyphosate (Roundup), as this herbicide will affect seed germination when applied to seed production fields. Sodium chlorate is best applied by ground for maximum coverage.

Harvesting is subject to the supervision of the county agricultural commissioner, who must be contacted prior to harvest. After the CCIA completes the three required field inspections, they issue a field inspection report. Once the seed company has the report and is ready to harvest, they notify the grower to contact the agricultural commissioner (or they contact the agricultural commissioner directly) for the harvester inspection. The agricultural commissioner's office will not inspect a harvester or authorize harvest until they confirm that CCIA has issued the field inspection report. A county agricultural commissioner biologist must inspect the harvester to verify that the harvester has been properly cleaned of any contaminating seed sources (CCIA 2015).

When approved, harvesting is usually done by growers using their own combine and header, when the seed moisture is less than 12 percent. Proper combine setup is essential to prevent seed loss and injury, excess foreign material, and weed seeds in the harvested product.

\section{CLEANING, GRADING, AND MARKETING}

Sunflower seeds are hauled to the warehouse for a precleaning, also known as scalping, to reduce the foreign material to 5 to 15 percent of the volume by the contracting seed company. The goal is to reduce the level of foreign matter to 3 percent or less to obtain 97 percent pure seed and to remove nonmarketable (undersized and oversized) seeds prior to sizing. After scalping, the seed is further cleaned to bring the product to 98 percent pure seed (CCIA's minimum standard) and to ensure desirable seed size. Growers will be docked if extra conditioning is needed, such as cleanout fees for low germination or impurities such as weed seeds.

All seed must be sampled and tested after conditioning (including cleaning and blending) and lots are certified as required by export markets. For certification, all samples drawn for seed analyses (testing) must be drawn by an Association of American Seed Control Officials (AASCO) accredited seed sampler. Currently, CCIA trains AASCO accredited seed samplers. Every 3 years, all accredited samplers must renew their accreditation by attending training seminars that CCIA conducts. If a company or conditioner does not have an accredited sampler on staff, an accredited individual from the agricultural commissioner's office will draw samples for them.

After the seed company submits information on the seed lot and seed analysis to CCIA, CCIA reviews it. When standards are met, CCIA issues a seed inspection report, after which, companies may request tags. If the seed is intended for shipment to a country that is a part of the OECD Seed Schemes (Organization for Economic Cooperation and Development that oversees controlling of seed traded internationally), a company must also apply through CCIA for an OECD certificate. The tags, OECD certificate, and phytosanitary certificate (from the agricultural commissioner) must accompany the shipment.

A seed transfer certificate is required anytime untagged seed moves, no matter where it is going outside of the county in which the seed is residing, such as from the field to conditioner, from conditioner to conditioner, from California to Minnesota, or from California to Chile. The three types of seed transfer certificates are inter-county, intra-county, and inter-agency (state).

The primary market for sunflower seed is Eastern Europe (mainly Russia and Ukraine), where more than 50 million acres of sunflowers are grown for cooking oil. Seed is also marketed and sent to the U.S. Midwest, where about 1.7 million acres of sunflowers are grown primarily for cooking oil, but also for confectionary seed, with the Dakotas being the top sunflower producer in the United States. Other hybrid sunflower seed producers include Turkey, Chile, and Argentina. 


\section{REFERENCES}

AASCO (Association of American Seed Control Officials). Website, http://www.seedcontrol.org/.

Ayers, R., and D. Westcot. 1994. Water quality for agriculture. Rome: Food and Agriculture Organization of the United Nations. FAO website, http://www.fao.org/docrep/003/T0234E/T0234E00.htm

Berglund, D. 2007, ed. Sunflower production. North Dakota State University Extension Service Bulletin A-1331, EB-25 Revised. North Dakota State Extension website, https://www.ag.ndsu.edu/ extensionentomology/recent-publications-main/publications/A-1331sunflower-production-field-guide.

CCIA (California Crop Improvement Association). 2015. Harvester cleanout inspection video. https://www.youtube.com/ watch?v=8YCTcwt0kMY.

$<3 \mathrm{M}>$. 2018a. Certified hybrid sunflower crop acreage reports from agricultural commissioners. CCIA website, http://ccia.ucdavis.edu/ Agricultural_Commissioners/.

$<3 \mathrm{M}>$. 2018b. California seed law and prohibited and restricted noxious weed list. University of California Division of Agriculture and Natural Resources CCIA website, http://ccia.ucdavis.edu/ Certification_Programs/Seed_Certification/California_Seed_Law/.

$<3 \mathrm{M}>2018$ c. Crop standards for certified sunflower seed production. CCIA website, http://ccia.ucdavis.edu/Crop_Standards_pages/ Sunflower/.

CDFA (California Department of Agriculture). 2015. Phytosanitary field inspection. CDFA website, http://phpps.cdfa.ca.gov/pe/ interiorexclusion/pdf/cropsdiseases\&inspections.pdf.

$<3 \mathrm{M}>$. 2018. Links to county crop reports. CDFA website, https://www. cdfa.ca.gov/exec/county/CountyCropReports.html.

CIMIS (California Irrigation Management Information System). 1999. Reference evapotranspiration California climate classifications map. NASA website, https://www.jpl.nasa.gov/edu/images/activities/ etozonemap.jpg.

Geisseler, D., and W. Horwath. 2016. Sampling for soil nitrate determination. University of California, Davis, Department of Land, Air, and Water Resources. CDFA website, https://apps1.cdfa.ca.gov/ fertilizerresearch/docs/Soil_Sampling_Nitrate.pdf.
Gulya, T., S. Rooney-Latham, J. Miller, et al. 2012. Sunflower diseases remain rare in California seed production fields compared to North Dakota. Plant Health Progress website, https://www. plantmanagementnetwork.org/pub/php/research/2012/sunflower/.

Harveson, R., S. Markell, C. Block, and T. Gulya. 2016. Compendium of sunflower diseases and pests. St. Paul: APS Press.

Hergert, G., W., and J., A. Schild. 2013. Fertilizer management for dry edible beans. Neb Guide G1713, 4 pp.

Long, R., S. Light, M. Galla, et al. 2018. Sample costs to produce sunflowers for hybrid seed in the Sacramento Valley. University of California Cooperative Extension Cost Studies website, http:// coststudies.ucdavis.edu.

O'Connor-Marer, P. 2006. Residential, industrial and institutional pest control. 2nd ed. Oakland: University of California Agriculture and Natural Resources Publication 3334.

Schneiter A., J. Miller, and D. Berglund. 2013. Stages of sunflower development. North Dakota State University Extension Service website, https://www.ag.ndsu.edu/publications/crops/stages-ofsunflower-development/a1145.pdf.

Snyder, L., M. Orang, K. Bali, et al. 2014. Basic irrigation scheduling program (BISe). Oakland: University of California Land, Air, and Water Resources Biomet website, http://biomet.ucdavis.edu/ irrigation_scheduling/bis/BIS.htm.

UC IPM. 2013. University of California Integrated Pest Management Pest Notes for pantry pests. UC IPM website, http://ipm.ucanr.edu/ PMG/PESTNOTES/pn7452.html.

USDA (United States Department of Agriculture). Phytosanitary Certificate Issuance and Tracking System. website, https://pcit.aphis. usda.gov/pcit/faces/signIn.jsf.

Venette J., T. Gulya, and R. Lamppa. 1994. Foamy head rot of sunflower. In Proceedings of the 16th Sunflower Research Workshop, Fargo, ND. Bismarck: National Sunflower Association. 46-49.

Vertebrate Pest Control Research Advisory Committee. Vertebrate Pest Control Handbook, http://vpcrac.org/about/vertebrate-pesthandbook/ 


\section{ACKNOWLEDGMENTS}

The authors wish to offer many thanks to contributors from Corteva (Dow AgroSciences, DuPont USA, Pioneer), the California Crop Improvement Association (CCIA), and reviewers from USDA-ARS, North Dakota State University (NDSU), and University of California Cooperative Extension (UCCE).

\section{FOR FURTHER INFORMATION}

To order or obtain ANR publications and other products, visit the ANR Communication Services online catalog at http://anrcatalog.ucanr.edu/ or phone 1-800-994-8849. Direct inquiries to

University of California

Agriculture and Natural Resources

Communication Services

2801 Second Street

Davis, CA 95618

Telephone 1-800-994-8849

E-mail: anrcatalog@ucanr.edu

(02019 The Regents of the University of California. This work is licensed under the Creative Commons Attribution-NonCommercial-NoDerivatives 4.0 International License. To view a copy of this license, visit http://creativecommons.org/licenses/by-nc-nd/4.0/ or send a letter to Creative Commons, PO Box 1866, Mountain View, CA 94042, USA.

Publication 8638

ISBN-13: 978-1-62711-080-8

https://doi.org/10.3733/ucanr.8638
The University of California, Division of Agriculture and Natural Resources (UC ANR) prohibits discrimination against or harassment of any person in any of its programs or activities on the basis of race, color, national origin, religion, sex, gender, gender expression, gender identity, pregnancy (which includes pregnancy, childbirth, and medical conditions related to pregnancy or childbirth), physical or mental disability, medical condition (cancerrelated or genetic characteristics), genetic information (including family medical history), ancestry, marital status, age, sexual orientation, citizenship, status as a protected veteran or service in the uniformed services (as defined by the Uniformed Services Employment and Reemployment Rights Act of 1994 [USERRA]), as well as state military and naval service.

UC ANR policy prohibits retaliation against any employee or person in any of its programs or activities for bringing a complaint of discrimination or harassment. UC ANR policy also prohibits retaliation against a person who assists someone with a complaint of discrimination or harassment, or participates in any manner in an investigation or resolution of a complaint of discrimination or harassment. Retaliation includes threats, intimidation, reprisals, and/or adverse actions related to any of its programs or activities.

UC ANR is an Equal Opportunity/Affirmative Action Employer. All qualified applicants will receive consideration for employment and/or participation in any of its programs or activities without regard to race, color, religion, sex, national origin, disability, age or protected veteran status.

University policy is intended to be consistent with the provisions of applicable State and Federal laws.

Inquiries regarding the University's equal employment opportunity policies may be directed to: Affirmative Action Contact and Title IX Officer, University of California, Agriculture and Natural Resources, 2801 Second Street, Davis, CA 95618, (530) 750-1397. Email: titleixdiscrimination@ucanr.edu. Website: http://ucanr.edu/sites/anrstaff/Diversity/ Affirmative_Action/.

To simplify information, trade names of products have been used. No endorsement of named or illustrated products is intended, nor is criticism implied of similar products that are not mentioned or illustrated.

An electronic copy of this publication can be found at the ANR Communication Services catalog website, http://anrcatalog.ucanr.edu/.

UC This publication has been anonymously peer reviewed for technical PEER accuracy by University of California scientists and other qualified REVIEWED professionals. This review process was managed by ANR Associate Editor for Agronomy and Range Science Daniel Putnam.

web-3/19-SB/WS 